\title{
Keratins regulate colonic epithelial cell differentiation through the Notch1 signalling pathway
}

\author{
Iris AK Lähdeniemi ${ }^{1}$, Julia 0 Misiorek ${ }^{1,6}$, Christian JM Antila ${ }^{1,2,6}$, Sebastian K-J Landor ${ }^{1,2,3}$, Carl-Gustaf A Stenvall ${ }^{1}$, Lina E Fortelius ${ }^{1}$, \\ Linda K Bergström ${ }^{1}$, Cecilia Sahlgren ${ }^{1,2,4,6}$ and Diana M Toivola ${ }^{\star, 1,5,6}$
}

Keratins $(\mathrm{K})$ are intermediate filament proteins important in stress protection and mechanical support of epithelial tissues. K8, K18 and $\mathrm{K} 19$ are the main colonic keratins, and $\mathrm{K} 8$-knockout $\left(\mathrm{K}^{-l-}\right)$ mice display a keratin dose-dependent hyperproliferation of colonic crypts and a colitis-phenotype. However, the impact of the loss of K8 on intestinal cell differentiation has so far been unknown. Here we show that K8 regulates Notch1 signalling activity and differentiation in the epithelium of the large intestine. Proximity ligation and immunoprecipitation assays demonstrate that $K 8$ and Notch1 co-localize and interact in cell cultures, and in vivo in the colonic epithelial cells. K8 with its heteropolymeric partner K18 enhance Notch1 protein levels and activity in a dose dependent manner. The levels of the full-length Notch1 receptor (FLN), the Notch1 intracellular domain (NICD) and expression of Notch1 downstream target genes are reduced in the absence of K8, and the K8-dependent loss of Notch1 activity can be rescued with re-expression of K8/K18 in K8-knockout CRISPR/Cas9 Caco-2 cells protein levels. In vivo, K8 deletion with subsequent Notch1 downregulation leads to a shift in differentiation towards a goblet cell and enteroendocrine phenotype from an enterocyte cell fate. Furthermore, the $\mathrm{K}^{-1-}$ colonic hyperproliferation results from an increased number of transit amplifying progenitor cells in these mice. K8/K18 thus interact with Notch1 and regulate Notch1 signalling activity during differentiation of the colonic epithelium. Cell Death and Differentiation (2017) 24, 984-996; doi:10.1038/cdd.2017.28; published online 5 May 2017

Keratins $(\mathrm{K})$ are the main intermediate filament proteins of epithelial cells where they have stress-protective roles in mechanical and non-mechanical functions. ${ }^{1}$ Keratins bind to desmosomes between epithelial cells maintaining tissue barriers and cell polarity, participate in the spatial organization of organelles and proteins ${ }^{2-4}$ and in the regulation of apoptosis and cell migration. ${ }^{5,6}$ In humans, K5 and $\mathrm{K} 14$ mutations lead to skin diseases, and mutations in K8, K18 or K19 predispose to liver diseases. ${ }^{6-8}$ Keratins are dynamically regulated by post-translational modifications where site-specific phosphorylation of, for example, K8 Serine (S) 74 is associated with mitosis, apoptosis and cell stress. ${ }^{9}$

In the colonic epithelium, the main keratin family members expressed are type II K7 and K8 that with type I K18-K20 form filaments by obligate type I-type II heteropolymerization. ${ }^{10} \mathrm{~K} 8$ is the most common type II keratin in the intestine, and $\mathrm{K}^{-/-}$ mouse colonocytes consequently lack most keratins. ${ }^{11,12}$ The $\mathrm{K}^{-/-}$mouse develops a colonic phenotype consisting of epithelial hyperproliferation, decreased apoptosis, altered chloride/sodium transport, diarrhea and a Th2-type ulcerative colitis, which is ameliorated with antibiotics. ${ }^{4,12-15}$ Heterozygote $\mathrm{K}^{+/-}$mice have intermediate levels of keratins compared to $\mathrm{K}^{+/+}$and $\mathrm{K}^{-/-}$, and display an intermediate colonic phenotype with increased hyperproliferation and altered ion transport, but do not develop colitis. ${ }^{4,11,15}$ The influence of keratins on colonic epithelial differentiation has not been investigated, but the $\mathrm{K}^{-/-}$hyperproliferation proposes a role for keratins in the balance of colonic epithelial differentiation and cell fate.

Renewal of the colonic epithelium is a continuous and tightly controlled process. Colonic epithelial stem cells located in the crypt bottom proliferate to form transit amplifying cells, which migrate towards the top of the crypt and differentiate into enterocytes, goblet cells and enteroendocrine cells (EEC). ${ }^{16}$ The main regulators of colonic epithelial cell differentiation are the Notch1, Wnt and Ephrin signalling pathways. ${ }^{17}$ Other pathways including bone morphology protein, hedgehog and growth factor signalling also have roles in renewal of the colonic epithelium. ${ }^{17}$ In the Notch1 pathway, a ligand binds the full-length Notch1 receptor (FLN) on an adjacent cell, inducing cleavage of the receptor generating the membrane-tethered $\Delta \mathrm{E}$-Notch form, which is subsequently cleaved by the $\gamma$-secretase complex to release the Notch1 intracellular domain (NICD). ${ }^{18,19}$ When released, NICD translocates to the nucleus and activates target gene transcription (for example Hey1, Hey2), which induces differentiation of transit amplifying cells towards enterocytes and inhibits the formation of goblet cells and EEC. ${ }^{19-24}$ It is poorly understood which molecular factors regulate Notch1 signalling and colonic epithelial cell differentiation. Here we report a novel interaction between keratins and Notch1, where K8/K18 increase Notch1 levels and enhance Notch1 signalling activity. We also

\footnotetext{
${ }^{1}$ Cell Biology, Biosciences, Faculty of Science and Engineering, Åbo Akademi University, Turku, Finland; ${ }^{2}$ Turku Center of Biotechnology, University of Turku and Åbo Akademi University, Turku, Finland; ${ }^{3}$ Department of Cell and Molecular Biology, Karolinska Institutet, Stockholm, Sweden; ${ }^{4}$ Technical University of Eindhoven, Eindhoven, The Netherlands and ${ }^{5}$ Turku Center for Disease Modeling, University of Turku, Turku, Finland

*Corresponding author: DM Toivola, Cell Biology/Biosciences, Faculty of Science and Engineering, Åbo Akademi University, Tykistökatu 6A, Turku, FIN-20520 Finland. Tel: +358 221 54092; E-mail: dtoivola@abo.fi

${ }^{6}$ These authors contributed equally to this work.

Received 26.5.16; revised 30.12.16; accepted 14.2.17; Edited by E Wagner; published online 05.5.2017
} 
demonstrate that the lack of $\mathrm{K} 8$ in vivo leads to decreased Notch1 levels and signalling activity associated with a shift in colonic epithelial cell differentiation towards a goblet cell phenotype.

\section{Results}

K8 interacts and co-localizes with Notch1. Keratins function as scaffolds regulating the activity and localization of proteins. ${ }^{6}$ To explore the possible role for keratins in the regulation of colonic epithelial homeostasis, K8/K18 immunoprecipitation was performed to analyse if $\mathrm{K} 8 / \mathrm{K} 18$ interact with known determinants of differentiation in the colon. NICD was co-immunoprecipitated in a complex with $\mathrm{K} 8 / \mathrm{K} 18$ from murine distal and proximal colon indicating that these proteins interact (Figure 1a and Supplementary Figure S1A). An antibody recognizing all forms of Notch1 was used to immunoprecipitate Notch1 from mouse embryonic fibroblasts lacking vimentin $\left(\mathrm{MEFvim}^{-/-}\right.$) and overexpressing NICD-GFP-Flag, $\triangle \mathrm{E}$ Notch1 or FLN, with and without $\mathrm{K} 8 / \mathrm{K} 18$, in order to confirm the binding and analyse which domain of Notch1 K8/K18 bind to. Western blot analysis revealed that $\mathrm{K} 8$ and $\mathrm{K} 18$ were co-immunoprecipitated from cells expressing NICD and the other Notch1 constructs (Figures 1b, c and Supplementary Figure S1B). These data support that K8/K18 interact with Notch1 at the NICD domain present in all constructs, ${ }^{18,19}$ as the NICD domain alone co-immunoprecipitated K8 (Figures $1 \mathrm{~b}$ and c). The phosphodeficient mutant protein K8 S74 to Alanine $(A)^{9}$ also co-immunoprecipitated with Notch1 (Figure 1b, lane 8 and c), indicating that the Notch-K8 binding is not K8 S74 phosphorylation dependent. Supportive of these data, is that epithelial human embryonic kidney HEK 293 cells that overexpress FLN (HEK FLN 293), ${ }^{25}$ and that also express K8/K18, co-immunoprecipitated FLN with a K18 antibody (Supplementary Figure S1C).

To further analyse the spatial relationship between $\mathrm{K} 8$ and Notch1, proximity ligation assay (PLA) was performed using $\mathrm{K} 8$ and Notch1 antibodies in Caco-2 human colorectal cancer cells. The PLA signal showed that Notch1 and K8 are closely localized in PLA-positive dots both at the cell membrane and in the cytosol in filamentous arrays (Figure 1dA-B and e). PLA assay with cyclooxygenase 1 (Cox1) (negative control) and Notch1 (Figure 1dC), or with Notch1 (Figure 1dD) or K8 (Figure 1dE) alone showed no or minor PLA signal, indicating that the $\mathrm{K} 8 /$ Notch1 proximity signal is specific (Figure 1e). The co-localization of Notch1 and K8 in Caco-2 cells was confirmed by double-immunofluorescence staining, using the rabbit-Notch1 C-20 Santa Cruz antibody (also used for PLA), recognizing FLN and all cleaved fragments of Notch1, and a rat-K8 antibody (Troma I). The staining showed that Notch1 co-localizes with typical K8-filaments in the cytosol (Supplementary Figure S2A), and forms filamentous patterns also when not stained for K8 (Supplementary Figure S2C). Similar Notch1/K8 patterns were seen in a different epithelial cell line, MCF7 breast cancer cells, using different K8 (273) and Notch antibodies (A6, Supplementary Figure S2B). Our observations demonstrate that $\mathrm{K} 8 \mathrm{co}-$ localizes and interacts with Notch1 both in vivo and in vitro in cell culture conditions.
Keratins enhance Notch1 levels and stabilize signalling activity in vitro. The interaction of Notch1 with $\mathrm{K} 8$ indicates a role for $\mathrm{K} 8$ in Notch1 regulation. We tested this hypothesis by investigating the influence of $\mathrm{K} 8 / \mathrm{K} 18$ on Notch 1 protein levels in $\mathrm{MEFvim}^{-1-}$ cells. Overexpression of K8/K18 in MEFvim $^{-1-}$ cells did not affect the endogenous FLN or NICD levels in this fibroblast cell line (Figures $2 a$ and b). In order to test whether K8/K18 can stabilize NICD levels in an artificial situation, we transfected cells with NICD together with $\mathrm{K} 8$ / K18. NICD levels were consistently 2-3 fold higher when overexpressing NICD with K8/K18 compared with NICD alone (Figures $2 \mathrm{c}$ and d), and the NICD levels increased in a keratin-dose-dependent manner (Figure 2e). Overexpression of phosphorylation-deficient $\mathrm{K} 8 \mathrm{S74A}$ was also able to increase NICD levels (Figures $2 \mathrm{c}$ and $\mathrm{d}$ ). In addition, overexpression of $\mathrm{K} 8$ with a different keratin partner, $\mathrm{K} 19$, with NICD, similarly to K8/K18 increased the NICD levels indicating that the NICD increase is K8-dependent but independent of its heterodimeric partner (Figure 2f). In order to test whether $\mathrm{K} 8$ affects Notch1 signalling levels, the effect of keratin overexpression in MEFvim ${ }^{-1-}$ cells on Notch1 target genes was analysed. Expression of the Notch1 target genes Hey1 and Hey2 was significantly increased when NICD was overexpressed together with $\mathrm{K} 8 / \mathrm{K} 18$ compared to NICD overexpression alone (Figure $2 \mathrm{~g}$ ). Overexpression of K8 S74A/K18 with NICD did not increase the mRNA levels of Hey1 or Hey2 (Figure 2g) suggesting that phosphorylation of K8 S74 may have a role in the regulation of Notch signalling activity. This is in contrast to the influence of keratin phosphorylation on Notch binding and NICD protein levels (Figure 1b, 2c, d and h). To determine whether K8/K18 stabilize NICD, the proteasome was inhibited with MG132 for $12 \mathrm{~h}$. A difference in NICD levels in cells expressing NICD and in cells expressing NICD with K8/K18 or K8 S74A/K18 could not be observed (Figures $2 \mathrm{~h}$ and $\mathrm{i}$ ), suggesting that keratins do not significantly affect the degradation speed of NICD. To inhibit protein translation, MEFvim ${ }^{-1-}$ cells overexpressing NICD alone or together with $\mathrm{K} 8 / \mathrm{K} 18$ or $\mathrm{K} 8 \mathrm{~S} 74 \mathrm{~A} /$ $\mathrm{K} 18$ were treated for 0,3 and $6 \mathrm{~h}$ with cycloheximide. Although the relative K8/K18-induced NICD levels decreased successively with a similar turnover rate as for NICD alone (Supplementary Figure S3A and C), the actual levels of NICD were consistently 2-3 fold higher if K8/K18 or K8 S74A/K18 were present (Supplementary Figure $3 A$ and B). Similarly, to test the turnover rate of FLN, Caco-2 cells where $\mathrm{K} 8$ had been knocked out using the CRISPR/Cas9 method were used. ${ }^{26}$ The turnover rate of endogenous FLN was similar in the presence or absence of keratins (Supplementary Figure S3D). In order to determine whether K8/K18 can affect the Notch subcellular localization, high salt extractions from $\mathrm{K}^{+/+}$and $\mathrm{K}^{-/-}$colon were analysed, and both FLN and NICD were detected in the high salt cytoskeleton fraction (Figure 2j). Together, these data suggest that keratins enhance Notch1 levels and signalling activity.

Notch1 levels and signalling activity are decreased in the $\mathrm{K}^{-I-}$ mouse colonic epithelium. We next analysed Notch1 signalling activity in the $\mathrm{K}^{-/-}, \mathrm{K}^{+/+}$and $\mathrm{K}^{+/-}$ mouse colonic epithelium in vivo. At the protein level, both FLN and NICD were significantly decreased more than 
threefold in $\mathrm{K}^{-/-}$mice (Figures $3 \mathrm{a}-\mathrm{c}$ ) compared to $\mathrm{K}^{+/+}$ mice. Immunohistochemical staining using an antibody against the NICD-cleaved epitope (recognizing the active NICD), confirmed that NICD was decreased in the $\mathrm{K}^{-1-}$ crypt (Figure $3 \mathrm{~dB}$ ). Colonic luminal bacteria can directly activate Notch1 target genes and differentiation. ${ }^{27}$ To verify that the Notch1 phenotype was a consequence of the loss of keratins and not of bacteria or inflammation, we treated mice a
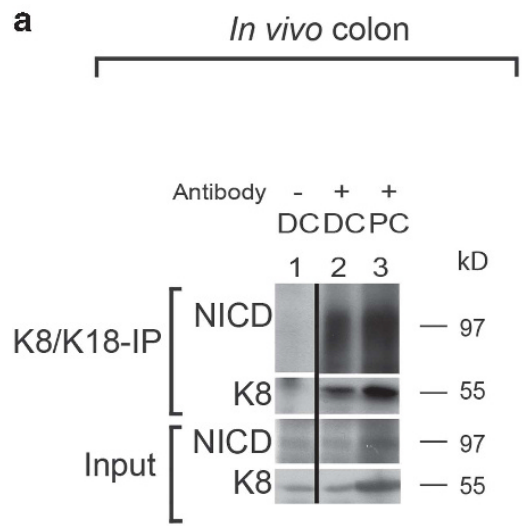

C

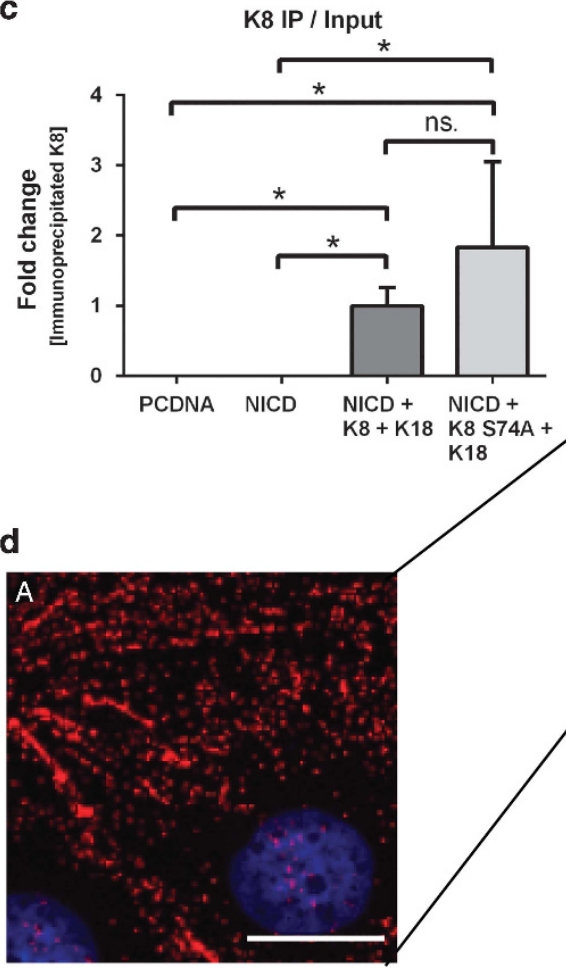

e b
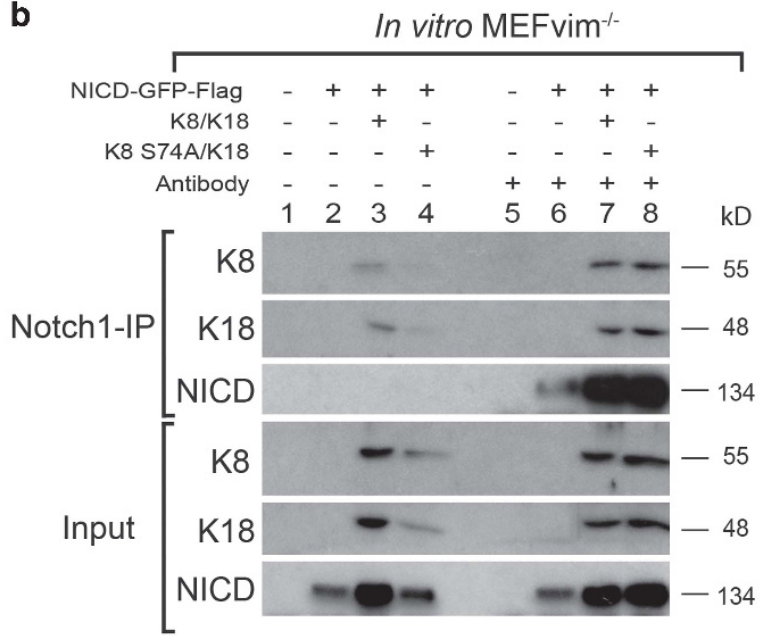

In vitro colon

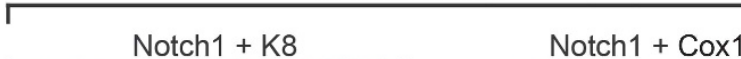

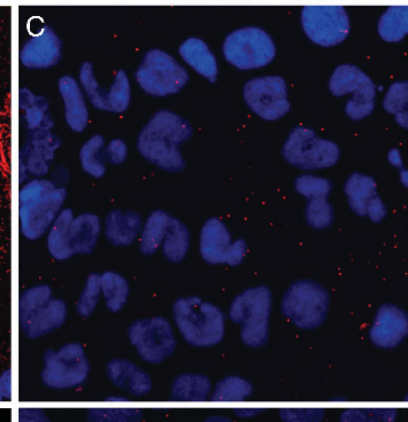

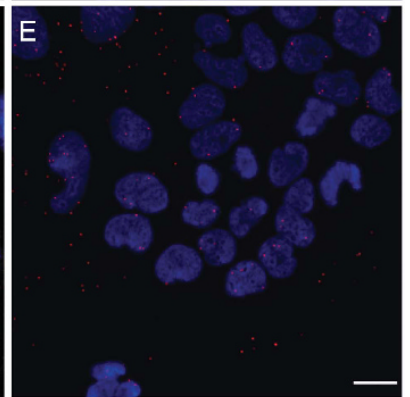

Notch1

K8 
with antibiotics to eliminate the intestinal microflora and ameliorate the $\mathrm{K}^{-/-}$colitis. ${ }^{13}$ The $\mathrm{K}^{-/-}$Notch1 phenotype was not dependent on intestinal bacteria and colonic inflammation as mice treated with broad-spectrum antibiotics for 8 weeks $^{13,14}$ showed a similar robust decrease in $\mathrm{K}^{-1-}$ FLN protein levels compared to $\mathrm{K}^{+/+}$mice (Figures $3 e$ and $\mathrm{f}$ ) as untreated mice (Figures $3 a$ and b). The FLN levels in $\mathrm{K}^{+/-}$ mice, which do not have colitis, were not affected under basal conditions, but displayed a mild decrease after antibiotics treatment compared to $\mathrm{K}^{+/+}$(Figures $3 e$ and f). The decrease was not statistically significant using one-way Anova analysis, but reached a $P$-value of 0.05 with Student's $t$-test. Notch1 mRNA levels remained unaltered in the $\mathrm{K}^{-1-}$ and $\mathrm{K}^{+/-}$colon (Figure $3 \mathrm{~g}$ ). In accordance with the reduced Notch1 protein levels in untreated mouse colon (Figures $3 a$ and b), expression of the Notch1 downstream target genes Hey1 and Hey2 was significantly decreased in $\mathrm{K}^{-/-}$colon (Figure $3 \mathrm{~h}$ ).

Notch1 levels and signalling activity are decreased in CRISPR/Cas9 $\mathrm{K}^{-I-}$ cells and rescued by $\mathrm{K} 8 / \mathrm{K} 18$ re-expression. To test whether $\mathrm{K} 8$ can stabilize endogenous Notch1 levels in the context of an epithelial colonic cell line, we analysed FLN and NICD levels and activity in CRISPR/ Cas9 $\mathrm{K}^{-1-}$ cells. K8-knockdown also leads to a deletion of $\mathrm{K} 18$ as $\mathrm{K} 18$ is degraded without its heteropolymeric partner $\mathrm{K} 8 .^{28,29}$ Similar to the $\mathrm{K}^{-1-}$ mouse colon (Figure 3a), both FLN and NICD levels were decreased in CRISPR/Cas9 $\mathrm{K}^{-/-}$cells compared to those in $\mathrm{K}^{+/+}$cells (Figures $4 \mathrm{a}-\mathrm{C}$ ). Hey1 mRNA levels were, consequently, 0.3-fold decreased in CRISPR/Cas9 $\mathrm{K}^{-/-}$compared to control $\mathrm{K}^{+/+}$cells (Figure 4d). This was further confirmed with immunofluorescence staining, indicating a dramatic loss in Notch1 after K8 deletion (Figure 4eD-F) compared to control CRISPR/Cas9 Caco-2 cells with keratins (Figure $4 \mathrm{eA}-\mathrm{C}$ ). The Notch1 phenotype could be rescued by overexpressing K8/K18 or $\mathrm{K} 8 \mathrm{~S} 74 \mathrm{~A} / \mathrm{K} 18$ in the CRISPR/Cas9 $\mathrm{K}^{-/-}$cells (Figure $4 \mathrm{eG}-\mathrm{L}$; see also Supplementary Figures S2C-D). Overexpression of $\mathrm{K} 8 / \mathrm{K} 18$ in CRISPR/Cas9 $\mathrm{K}^{+/+}$cells further increased Notch1 levels (Figure 4eM-O) compared to that in untransfected $\mathrm{K}^{+/+}$cells (Figures $4 \mathrm{~A}-\mathrm{C}$ ). To test whether cells rescued with $\mathrm{K} 8 / \mathrm{K} 18$ have functional NICD, cells were stained for Hey1. Similar to Notch levels (Figure 4), Hey1 levels were decreased in CRISPR/Cas9 $\mathrm{K}^{-1-}$ cells
(Figures $5 \mathrm{~d}-\mathrm{f}$ ) compared to $\mathrm{K}^{+/+}$cells (Figures $5 \mathrm{a}-\mathrm{C}$ ). The Hey1 phenotype could further be rescued by overexpression of $\mathrm{K} 8 / \mathrm{K} 18$ in $\mathrm{K}^{-/-}$cells (Figures $5 \mathrm{~g}-\mathrm{i}$ ) indicating that Notch signalling is active in cells rescued with $\mathrm{K} 8 / \mathrm{K} 18$. The rescue of Hey1 was not obvious with K8 S74A/K18 (Figures 5j-l) indicating, similarly to the Hey1 mRNA results (Figure 2g), that the keratin-dependent Notch1 activation of its target genes may be dependent on K8 phosphorylation. As the K8-dependent Notch1 phenotype was rescued in a dosedependent manner with K8/K18 overexpression, the data suggest that keratins modulate Notch1 protein levels and signalling activity in vivo in the mouse colonic epithelium and in Caco-2 colonic epithelial cells.

The lack of keratins leads to altered colonic epithelial cell differentiation towards a secretory cell fate. To test whether $\mathrm{K} 8$ deletion affects the colonic epithelial cell differentiation in accordance with its effect on Notch1, we analysed EEC, enterocytes and goblet cells in the crypt. The Notch1 signalling pathway is the main regulator of colonic epithelial cell differentiation inducing enterocyte differentiation while inhibiting goblet cell and EEC differentiation. ${ }^{20-23}$ The cell composition and/or pattern in the epithelial layer was analysed using the brush-border protein villin and carbonic anhydrase 2 (CA2) as markers for enterocytes, ${ }^{30}$ mucus as a marker for goblet cells ${ }^{20}$ and synaptophysin as a marker for EEC. ${ }^{31}$ Villin levels were decreased in the $\mathrm{K}^{-/-}$colon compared to $\mathrm{K}^{+/+}$ and $\mathrm{K}^{+/-}$(Figures $6 \mathrm{a}$ and $\mathrm{b}$ ), suggesting a reduced number of enterocytes in $\mathrm{K}^{-/-}$mouse colon. The enterocyte secretion product $C A 2^{20}$ mRNA levels were also significantly decreased in $\mathrm{K}^{-1-}$ mice (Figure $6 \mathrm{c}$ ), supporting a reduced number of enterocytes. $\mathrm{K}^{+/-}$enterocyte markers were partially, but consistently, decreased, but did not reach statistical difference (Figures 6a-c).

Alcian blue staining highlights acidic mucus in intestinal goblet cells and can be used to analyse the number of goblet cells. $^{32}$ Quantification (Figure $6 \mathrm{~d}$ ) of Alcian blue staining (Supplementary Figure S4) demonstrated that the number of goblet cells in relationship to the total number of cells in a crypt was significantly increased in both $\mathrm{K}^{-/-}$and $\mathrm{K}^{+/-}$distal colon and $\mathrm{K}^{-/-}$proximal colon, but not in $\mathrm{K}^{+/-}$proximal colon compared to $\mathrm{K}^{+/+}$(Figure $6 \mathrm{~d}$ ). Staining of goblet cells with periodic acid Schiff (PAS) showed similar results (not

Figure $1 \mathrm{~K} 8$ binds to and co-localizes with Notch1 in immunoprecipitation and PLAs. (a) Proximal (PC) and distal (DC) parts of the colon epithelium were isolated by scraping and homogenized with immunoprecipitation lysis buffer. For K8/K18 immunoprecipitation, the lysates were precleared with protein-G/Sepharose beads and incubated overnight with beads and K8/K18 antibodies. The immunoprecipitates were analysed with SDS-PAGE and immunoblotting with the indicated antibodies. Input samples were collected before the immunoprecipitation. The black vertical line in the figure indicates that empty wells have been cut out from the immunoblot without affecting the horizontal level of the bands (full blots are presented in Supplementary Figure S1A). Separate negative control samples where no antibody was added (-antibody) were prepared from the same DC sample that was used for immunoprecipitation and treated the same way as the other samples except for the omission of antibody. The input results shown in the DC-antibody sample in lane 1 are the same input sample western blot result as in the DC sample, lane 2. $n=4$. (b) Cells were transfected with the indicated plasmids, and the samples were collected and lysed for Notch1 immunoprecipitation and input (Input) as described in (a) $24 \mathrm{~h}$ after transfection. The no antibody controls (lanes 1-4) and the precipitates (lanes $5-8$ ) were precleared and incubated overnight with either beads alone or beads+goat anti-full length Notch1 $c-20$ antibody recognizing all Notch forms. The immunoprecipitates were analysed with SDS-PAGE and immunoblotting with the indicated antibodies (rabbit anti-full length Notch c-20 for Notch1), $n=6$. (c) K8 protein levels from immunoprecipitates (in (b)) were quantified and compared to the K8 input signals. The no antibody signal was subtracted from the immunoprecipitate signals and normalized to input levels. Negative values for PCDNA and NICD were set to $0 . n=3$. ${ }^{*} P<0.05$. (d) PLA was performed for Notch1 and K8 (dA, and which is zoomed from dB) in Caco-2 cells fixed with methanol and acetone at $-20^{\circ} \mathrm{C}$. The PLA signal (red) for Notch1 and K8 was analysed using rabbit anti-full length Notch1 C-20 (FLN and NICD) and mouse anti-K8 antibody in the proximity ligation kit from Duolink. Negative controls used were PLA signals for Notch1 and Cox1 (C), and background signals for Notch1 (D) and K8 (E) alone. Nuclei are presented in blue. $n=3$. Scale, $20 \mu \mathrm{m}$. (e) Quantification of PLA spots per cell in (d) was performed using particle analysis in Fiji. $n=5-13$ cells/ analysis. ${ }^{\star \star \star} P<0.001$ 
shown). The mRNA levels of the goblet cell products Mucin1 and Mucin ${ }^{33}$ were decreased in $\mathrm{K}^{-1-}$ colon (Figure 6e), suggesting that also the terminal differentiation of goblet cells may be disrupted. Thereby, our results demonstrated that $\mathrm{K}^{-/-}$and $\mathrm{K}^{+/-}$have an increased differentiation towards the secretory goblet cell fate.

Colonic EECs were analysed by immunoblotting using synaptophysin as a marker, and the levels in the $\mathrm{K}^{-/-}$mouse colon were increased compared to $\mathrm{K}^{+/+}$(Figures $6 \mathrm{f}$ and $\mathrm{g}$ ). Immunofluorescence staining confirmed the increased number of synaptophysin-positive EEC cells which are concentrated to the $\mathrm{K}^{-1-}$ crypt bottom (Figure $6 \mathrm{hB}$ ), in contrast to the lower EEC numbers in $\mathrm{K}^{+/+}$(Figure $6 \mathrm{hA}$ ) and $\mathrm{K}^{+/-}$ (Figure 6hC) colon. Taken together, our results show decreased protein levels of villin, and increased number of goblet cells and levels of synaptophysin in $\mathrm{K}^{-1-}$ and partly in a

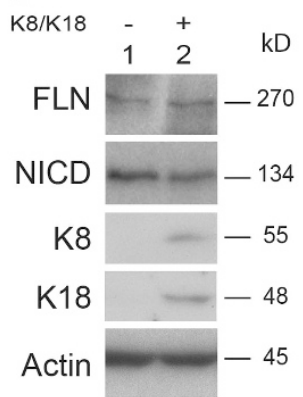

b

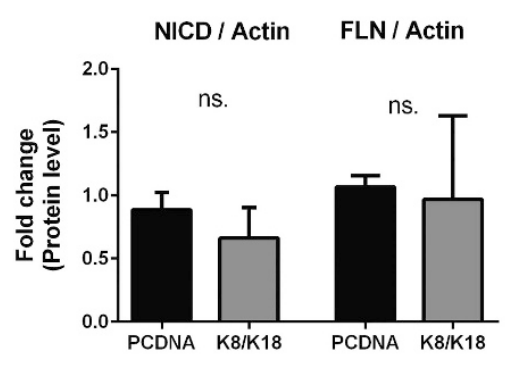

c

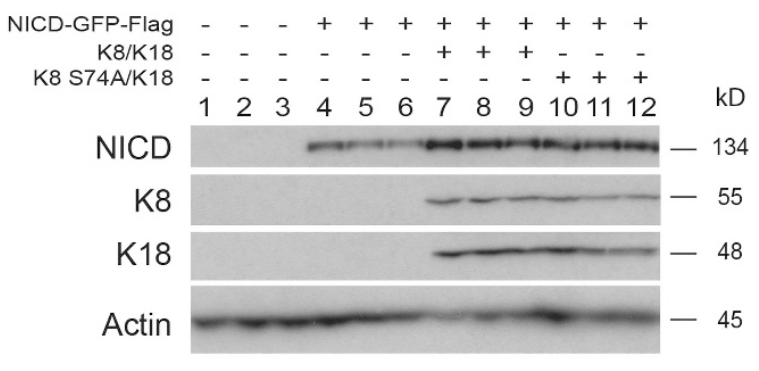

f d

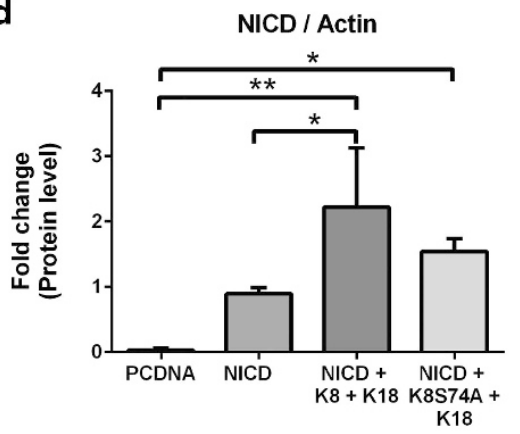

g

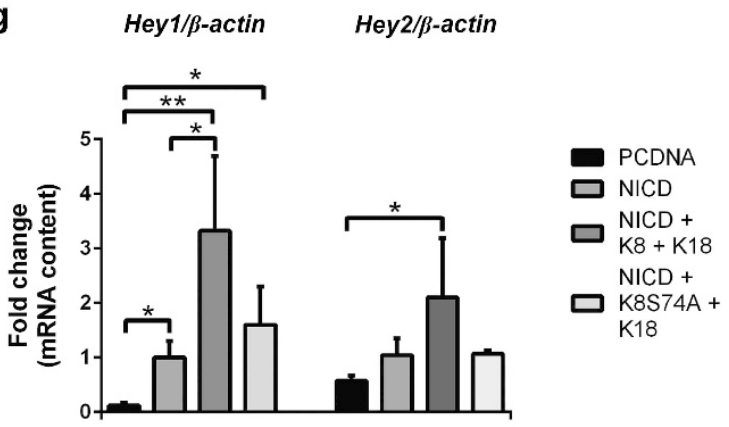

i

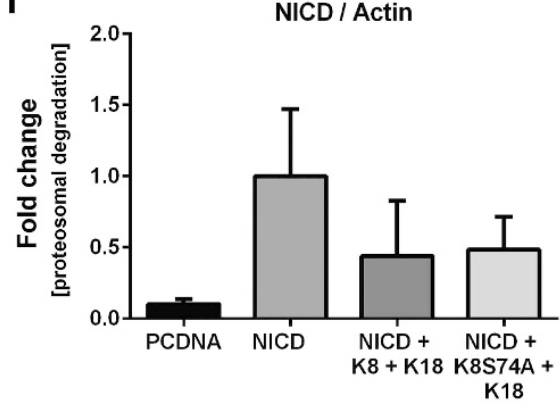

e
NICD-GFP-Flag ++

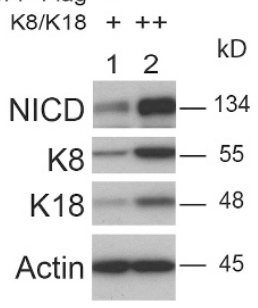

h

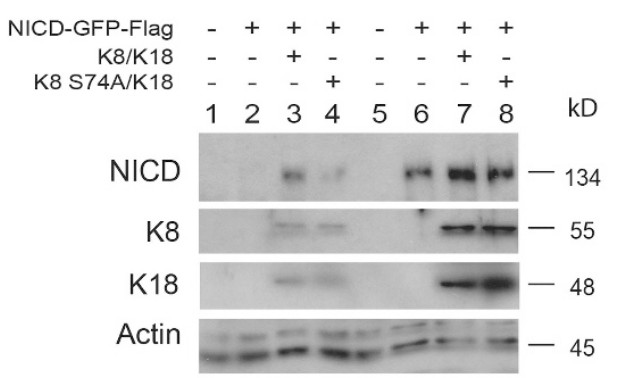

j

Colon High Salt Extraction

$$
\mathrm{K}^{+/+} \mathrm{K}^{-1-} \mathrm{K} 8^{+/-}
$$$$
\begin{array}{llll}
1 & 2 & 3 & \mathrm{kD}
\end{array}
$$

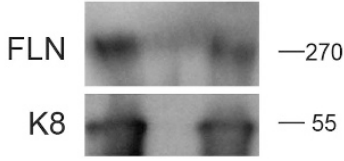


$\mathrm{K}^{+/-}$, which indicates that keratins might modulate lineage specification in colonic crypts in a dose-dependent manner through Notch1.

K8 inactivation leads to a widened proliferative zone and an increased number of transit amplifying cells in the mouse colon. The differentiation of colonic epithelial cells was clearly shifted towards secretory cell types, so the number of transit amplifying cells, from which the terminally differentiated cells originate, was investigated. ${ }^{16}$ Phosphohistone $\mathrm{H3}$ ( $\mathrm{PHH} 3$, marker of proliferative/ transit amplifying cells ${ }^{34}$ ) was significantly higher in both $\mathrm{K}^{-/-}$and $\mathrm{K}^{+/-}$mice colonic epithelium compared to $\mathrm{K}^{+/+}$when normalized to histone $\mathrm{H} 3$ (Figures 7a and b), indicating a dose-dependent increase in transit amplifying cells with reduced K8 levels (Figure 7a). Immunofluorescence staining confirmed the increased number of transit amplifying cells in the proliferative zone of the colonic crypts of $\mathrm{K}^{-/-}$and $\mathrm{K}^{+/-}$(Figure $7 \mathrm{c}$ ). These observations indicate that the keratin dose-dependent colonic epithelial hyperproliferation ${ }^{11}$ is caused by an increased number of transit amplifying cells and a widened proliferative zone leading to longer crypts. ${ }^{4}$

\section{Discussion}

We here describe a novel in vivo K8/K18-Notch1 interaction that has physiological importance for the differentiation of epithelial cells in the large intestine. We show with co-immunoprecipitation and PLA that $\mathrm{K} 8$ and $\mathrm{K} 18$ interact with Notch1 in vivo and in vitro. K8/K18 enhance Notch1 levels, promote downstream NICD activity and Notch1 target gene transcription. This association is supported by in vitro findings with CRISPR/Cas $9 \mathrm{~K}^{-/-}$cells and MEFvim ${ }^{-/-}$, and in vivo findings where the loss of keratins in the colon leads to a dramatic decrease in Notch1 levels and signalling. In addition, the K8-dependent Notch1 phenotype can be rescued by re-expressing $\mathrm{K} 8 / \mathrm{K} 18$ in $\mathrm{K}^{-1-}$ cells. The K8 knockdowninduced reduction in Notch1 signalling causes a characteristic $^{19}$ intestinal epithelial cell fate shift, with an increased number of colonic goblet cells, transit amplifying cells and EEC, and a decreased number of enterocytes (summarized in Figure 8). The $\mathrm{K}^{-/}$- phenotype is in line with the well-known effect of Notch inhibition, where blocking the cleavage of FLN to NICD by the gamma secretase inhibitor DAPT leads to goblet cell hyperplasia. ${ }^{22,35,36}$ The $\mathrm{K}^{+/-}$ mouse colon has a partial intermediate proliferation and differentiation phenotype compared to $\mathrm{K}^{-/-}$and $\mathrm{K}^{+/+}$mice (Supplementary Table S1), in line with the milder effect on Notch1 levels seen after antibiotics treatment (Figures $3 e$ and $\mathrm{f}$ ). Although it is unclear whether the $50 \%$ decrease of $\mathrm{K} 8$ in $\mathrm{K}^{+/-}$mice is sufficient to significantly alter colonic Notch1 signalling, we here demonstrated in MEFvim ${ }^{-1-}$ cells a dose dependency of K8/K18 levels on the stability of NICD. To our knowledge, this is the first study showing that the structural and stress protector intermediate filament proteins participate in maintaining cell fate and differentiation through interaction with Notch1 affecting Notch1 activity and Notch1 target gene transcription.

The $\mathrm{K}^{-/-}$colon differentiation phenotype with more goblet cells is in accordance with the decreased Notch1 signalling activity and a shift in cell fate. However, the mucin mRNA levels appear to be compromised in the $\mathrm{K}^{-/-}$, possibly indicative of problems in terminal goblet cell differentiation. This may be related to a previous description of abnormal containment of $\mathrm{K}^{-/-}$goblet mucus vacuoles. ${ }^{4} \mathrm{We}$ cannot rule out that $\mathrm{K}^{-1-}$ mice would not have a problem with terminal differentiation of colonic epithelial cell. As of note, deletion of $\mathrm{K} 9$ has been shown to lead to impaired terminal differentiation in epidermis, ${ }^{37}$ and $\mathrm{K} 17$ has been reported to have a role in the terminal differentiation in cervical epithelium. ${ }^{38}$ We further observe an elevated number of transit amplifying cells in colonic crypts after $\mathrm{K} 8$ deletion, which supports the previously described hyperproliferation phenotype, ${ }^{4,11-13}$ and identifies the cell source of the increased proliferation in $\mathrm{K}^{-/-}$mice, in line with previous reports on hyperproliferation in the intestine. $^{39}$ To that end, K19 was recently found to mark Lgr5-radioresistant cancer stem cells in the colonic epithelium, ${ }^{40}$ proposing a role for keratins in the crypt base compartment together with the Notch1 pathway as we here show that type I K19 is a similarly good partner to K8 as is K18 with respect to stabilizing NICD levels. Taken together, these data suggest that keratins have multifaceted roles in processes of tissue differentiation and turnover.

K8/K18 interact with Notch1, and the decreased NICD levels and signalling activity in the colon of the K8-knockout mice explain the observed goblet cell hyperplasia. Keratins are known to aid in protein localization, and intermediate filament proteins' mutations or deletion lead to mistargeting of membrane proteins. ${ }^{4,41-43}$ As keratins do not affect Notch1 mRNA levels, FLN or NICD turnover, nor NICD degradation, it

Figure 2 Keratins enhance and stabilize Notch levels. (a-d) MEFvim ${ }^{-1-}$ cells were cultured and transfected by electroporation with the indicated plasmids. FLN, NICD and K8/ K18 protein levels were analysed with SDS-PAGE and immunoblotting. Actin was used as a loading control. The endogenous protein amounts of FLN and NICD from (a) were quantified in (b), and from (c) were quantified in (d) by normalization to the loading control actin. Lanes 1-12 in (c) represent the different cell samples $(n=3)$. Lane 1 in (a) and lanes $1-3$ in (c) represent transfection with an empty plasmid (PCDNA3.1). ${ }^{*} P<0.05,{ }^{* *} P<0.01$. (e) MEFvim ${ }^{-1}$ - cells were cultured and transfected by electroporation with $10 \mu \mathrm{g}$ $\mathrm{NICD}$ and $5(+)$ and $10(++) \mu \mathrm{g}$ of K8 and K18. NICD and K8/K18 protein levels were analysed by immunoblotting. Actin was used as a loading control. $n=3$. (f) MEFvim ${ }^{-1-}$ cells were cultured and transfected and analysed by western blotting as in (c) with the addition of K19. Actin was used as a loading control. Lane 1 represents transfection with an empty plasmid (PCDNA3.1). $n=4$. (g) MEFvim ${ }^{-1}$ - cells were cultured and transfected as indicated in (c) and Hey1 and Hey2 mRNA amounts were analysed with RT-PCR, normalized to $\beta$-Actin and presented as average fold change as related to NICD overexpressed control cell samples \pm SD. $n=3 .{ }^{*} P<0.05 .{ }^{\star \star} P<0.01$. (h) MEFvim ${ }^{-1-}$ cells were transfected by electroporation of the indicated plasmids. $24 \mathrm{~h}$ after transfection, cells were treated for $12 \mathrm{~h}$ with $20 \mu \mathrm{M} \mathrm{MG} 132$. Cell lysates were analysed with SDS-PAGE and immunoblotting using the indicated antibodies. Actin was used as a loading control. Lanes 1 and 5 represent transfection with an empty plasmid (PCDNA3.1), $n=3$. (i) The NICD levels in (h) were normalized to the loading control actin, whereafter the NICD levels in MG132 treated cells were normalized to control cells to obtain average fold change proteosomal degradation. Data are presented as average fold change and related to NICD-overexpressed control cell samples \pm S.D. $n=3$. (j) Colon from K8 $8^{+/+}, \mathrm{K}^{-1-}$ and $\mathrm{K}^{+/+}$mice were subjected to high salt extraction, and the cytoskeletal fraction was analysed by SDS-PAGE and immunoblotting for FLN and K8 
a

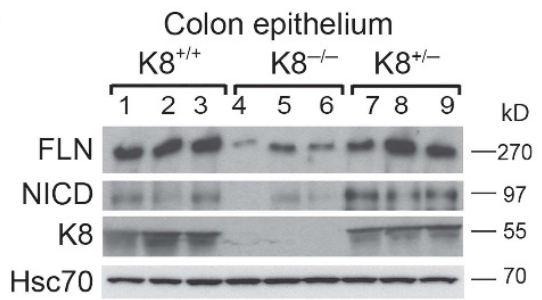

b

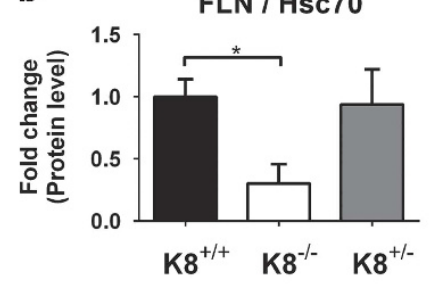

c

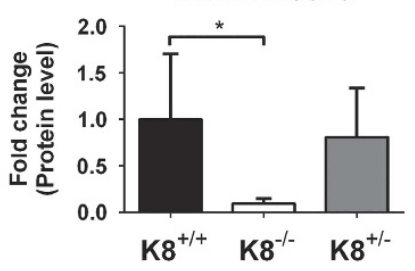

d

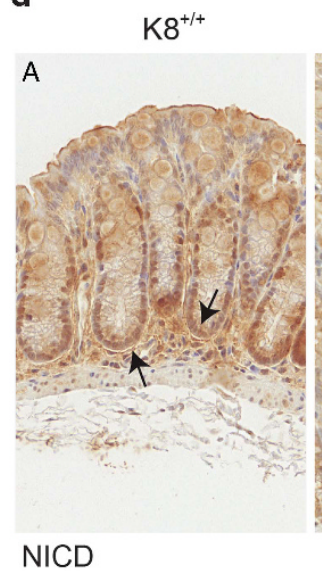

$\mathrm{K}^{-/-}$
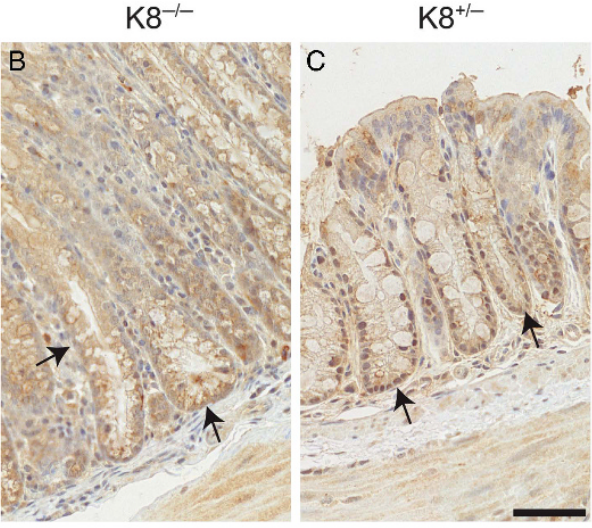

e

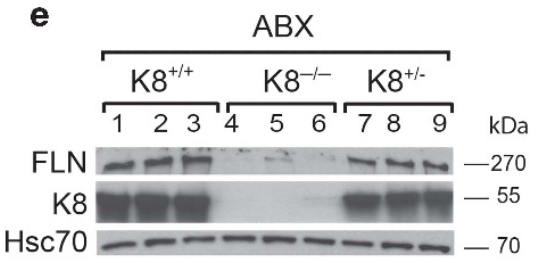

f
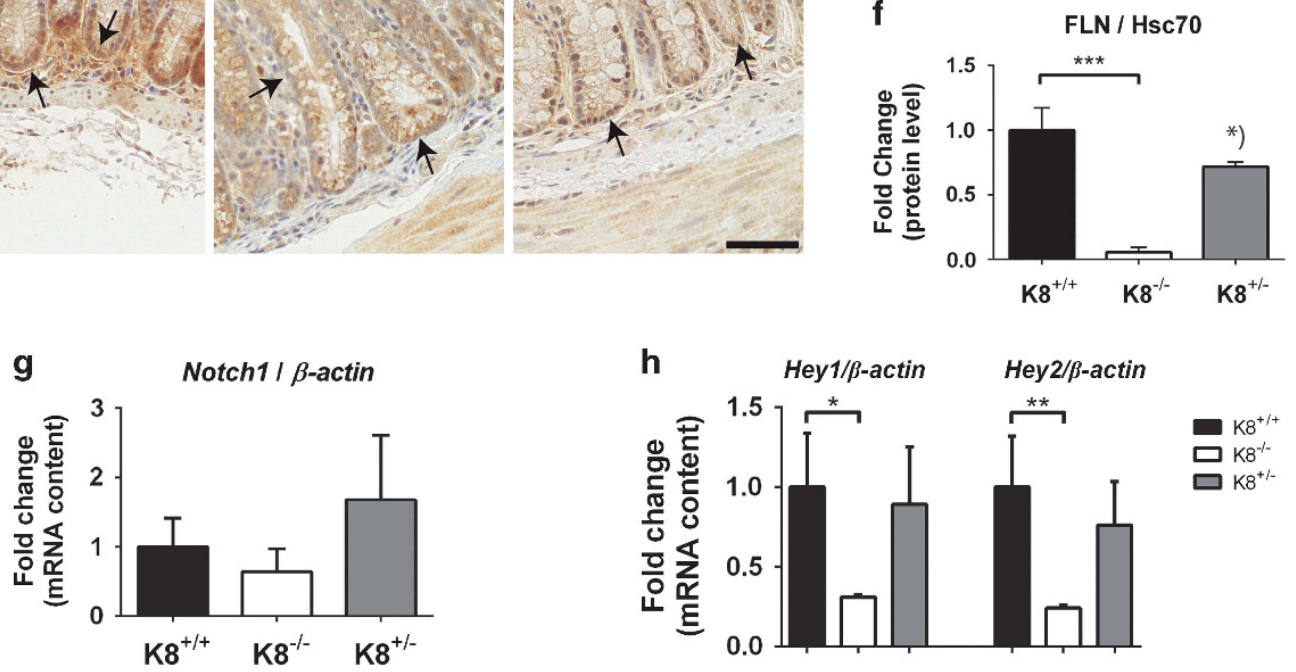

Figure 3 FLN and NICD are decreased in $\mathrm{K}^{-1-}$ mouse colon. (a) Colonic epithelium isolated by scraping was used for analysis of FLN and NICD protein amounts with SDS-PAGE and immunoblotting. The genotypes $\left(\mathrm{K}^{+/+}, \mathrm{K}^{-1-}\right.$ and $\left.\mathrm{K} 8^{+/-}\right)$were confirmed by $\mathrm{K} 8$ immunoblotting, and Hsc70 was used as a loading control. Lanes $1-9$ represent individual mice. $n=3$. (b and $\mathbf{c}$ ) The protein amount of FLN and NICD from (a) was quantified and normalized to the loading control Hsc70. $n=3$. The results are presented as average fold change as related to $\mathrm{K}^{+/+}$control mice $\pm S D$. ${ }^{*} P<0.05$. (d) Immunohistochemical staining for NICD was performed on paraffin-embedded colon sections using rabbit anti-cleaved Notch1 antibody as indicated. $n=3$. Scale, $50 \mu \mathrm{m}$. Arrows point to positive signal in the crypt regions. (e) Mice were treated with broad-spectrum antibiotics (ABX) for 8 weeks after which the protein levels of FLN and K8 were analysed with SDS-PAGE and immunoblotting in colonic epithelial scraping samples. Hsc70 was used as a loading control. $n=3$. (f) FLN protein levels from (e) were quantified, normalized against the loading control $\mathrm{Hsc70}$ and presented as average fold change as related to $\mathrm{K} 8^{+/+}$ control mice $\pm \mathrm{SD}$. $\left.{ }^{* *} P<0.001 .{ }^{*}\right) \mathrm{K} 8^{+/-}$mice did not show a significant difference in FLN levels compared to $\mathrm{K}^{+/+}$by one-way Anova, whereas with Student's $t$-test the $P$ value was 0.05. (g) Notch1 mRNA levels were analysed with RT-PCR in the indicated mouse genotypes, normalized to $\beta$-Actin mRNA and presented as average fold change \pm SD. $n=3$. (h) mRNA levels of Notch target genes Hey1 and Hey2 were analysed with RT-PCR in the indicated mouse genotypes, were normalized to $\beta$-Actin and presented as average fold change as related to $\mathrm{K} 8^{+/+}$control mice $\pm \mathrm{SD} . n=3 .{ }^{*} P<0.05,{ }^{* *} P<0.01$

is conceivable that keratins could assist the transport of FLN to the plasma membrane. How keratins or other intermediate filament proteins do this is still elusive and needs further study. Post-translational modifications of keratins affect the binding to many keratin-associated proteins, including signalling intermediates, linker proteins and kinases. ${ }^{44,45}$ Cytoplasmic keratins might, thus, prolong NICD activity by stabilizing and retaining a pool of NICD in the cytoplasm, facilitate Notch1 receptor cleavage, and/or affect FLN stability. Interestingly, keratins interact with 14-3-3, which was recently shown to affect nuclear translocation of Notch $4 .{ }^{46}$ As the phosphodeficient mutant K8 S74A can bind and stabilize Notch1, but demonstrates reduced Notch1 target gene activation, the phosphorylation of K8 may have a role in some steps of this process. K8 $\mathrm{S} 74$ phosphorylation is a major dynamic K8 phosphorylation site in cell stress, cell division and apoptosis. ${ }^{9,47} \mathrm{~K} 8 \mathrm{~S} 74$ phosphorylation, which renders keratin filaments more soluble, ${ }^{9}$ could release NICD from keratin filaments and promote nuclear translocation and Notch1 target gene transcription.

A few other studies support a link between Notch1 and intermediate filament proteins. The expression of nestin, a marker for neural stem cells, is regulated by Notch $1,{ }^{48}$ and Notch1 activity as well as the expression of nestin decreases during differentiation. ${ }^{49}$ Astrocyte intermediate filament proteins regulate the Notch ligand Jagged to Notch1 signalling, and $\mathrm{GFAP}^{-1-} \mathrm{Vim}^{-1-}$ astrocytes show reduced endocytosis of Jagged1 with reduced Notch1 signalling in neuronal stem cells 
a

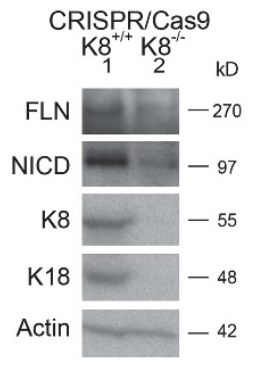

b

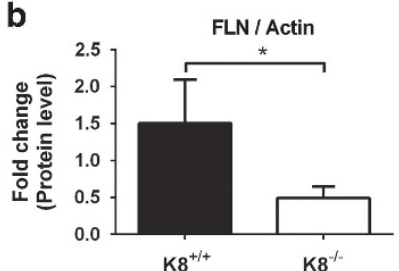

C

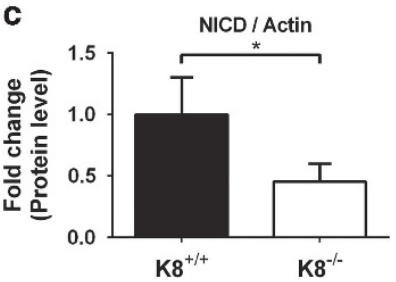

d

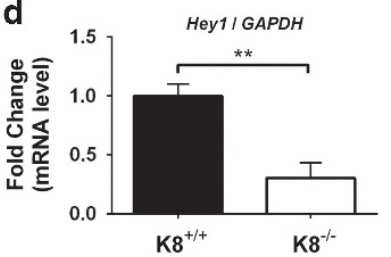

e
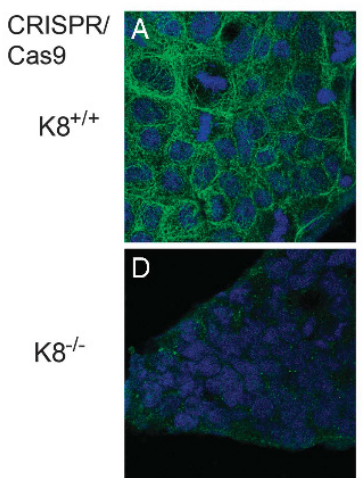

$\mathrm{K}^{-/-}$
+
$\mathrm{K} 8 / \mathrm{K} 18$

Rescue

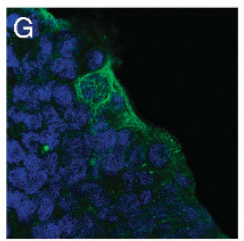

$\mathrm{K}^{-/-}$
+
$\mathrm{K} 8 \mathrm{~S} 74 \mathrm{~A}$
K18
Rescue
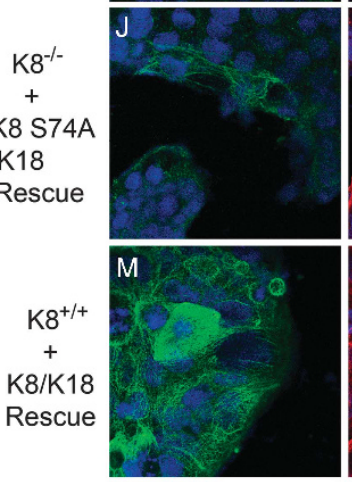

K8
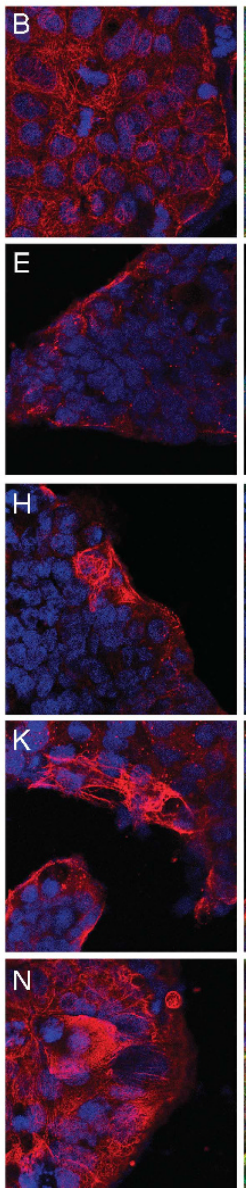
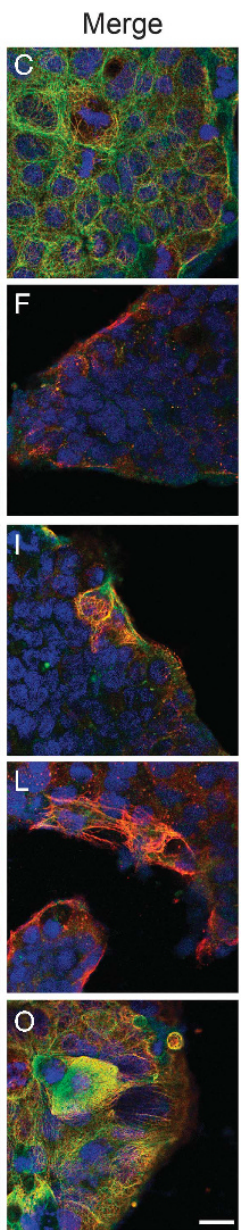

Figure 4 K8 deletion with the CRISPR/Cas9 method in Caco-2 cells downregulates Notch1 levels, which are rescued by re-expression of K8/K18 or K8 S74A/K18. (a) Caco-2 CRISPR/Cas9 $\mathrm{K}^{+/+}$and $\mathrm{K}^{-1-}$ cells were cultured, lysed for protein analysis and analysed with the indicated antibodies. Actin was used as a loading control. $n=5$. (b and $\mathbf{c}$ ) The FLN and NICD protein levels in (a) were quantified and normalized to the loading control actin. $n=3$. The results are presented as average fold change as related to $\mathrm{K}^{+/+}$control cells $\pm \mathrm{SD}$. ${ }^{*} P<0.05$. (d) Notch target gene Hey1 was analyzed in Caco-2 CRISPR/Cas $9 \mathrm{~K}^{+/+}$and $\mathrm{K}^{-/-}$cells with RT-PCR, normalized to $\beta$-Actin mRNA and presented as average fold change \pm S.D. $n=3$. (e) Caco-2 CRISPR/Cas9 K8 ${ }^{+/+}(\mathrm{A}-\mathrm{C}, \mathrm{M}-\mathrm{O})$ and Caco-2 CRISPR/Cas9 K8 ${ }^{-/-}$(D-L) cells were cultured on cover slips, and K8/ $\mathrm{K} 18$ or K8 S74A/K18 were overexpressed in Caco-2 CRISPR/Cas9 K8 ${ }^{-1-}(\mathrm{G}-\mathrm{L})$, and K8/K18 in Caco-2 CRISPR/Cas9 K8 ${ }^{+/+}$(M-0) cells with Lipofectamine 2000. Cells were fixed with methanol and acetone in $-20^{\circ} \mathrm{C}$ and immunostained for Notch1 (A, D, G, J, M) and K8 (B, E, H, K, N) and showed separately, or merged (C, F, I, L, O). Nuclei are presented in blue. $n=3-6$. Scale, $20 \mu \mathrm{m}$

promoting neurogenesis. ${ }^{50} \mathrm{~K} 14$ siRNA knockdown in skin increase the levels of Notch $1,{ }^{51}$ and Notch1 downregulation decreases K13 and K15, but increases K17 levels. ${ }^{52}$ Further recent support for a keratin-Notch link is that Notch2 was decreased in K19-knockout mouse livers in the common bile duct ligation-injury model. ${ }^{53}$

In summary, the loss of keratins leads to a robust decrease in Notch1 which is linked to a shifted cellular differentiation in colonic epithelia. Keratins and Notch1 interact, leading to enhanced Notch1 stability and target gene transcription (Figure 8). These novel findings suggest that keratins are important regulators of Notch1 signalling activity and differentiation of colonic epithelial cells.

\section{Materials and Methods}

Experimental animals, sample collection and antibiotic treatment. $\mathrm{K}^{+/+}, \mathrm{K}^{-/-}$and $\mathrm{K}^{+/-}$mice in the $\mathrm{FVB} / \mathrm{n}$ background ${ }^{12}$ and of 4-6 months of age were used in this study. The mice were age- and sex-matched and genotyped as previously described. ${ }^{12,54}$ After being killed by $\mathrm{CO}_{2}$ inhalation, colonic epithelial cells were isolated by scraping the lumen side of the colon with an ice-cold glass slide, ${ }^{55}$ and total colon samples were collected from the $1-\mathrm{cm}$ central part of the colon. Samples were used for western blot, immunoprecipitation, RT$\mathrm{PCR}$, and high salt extraction and immunostainings. For depleting the colonic microflora, $\mathrm{K}^{+/+}, \mathrm{K}^{-1-}$ and $\mathrm{K}^{+/-}$mice were treated with the broad-spectrum antibiotics vancomycin and imipenem (Hospira, IL, USA) administered in drinking water at $68 \mathrm{mg} / \mathrm{kg}$ body weight/day for 8 weeks starting at 18-19 days postnatally. ${ }^{13}$ The drinking water containing antibiotics was changed three times a week. Control mice received normal drinking water. Animal experiments were approved by and carried out in accordance with the National Animal Experiment Board and conformed to the regulations set by The Finnish Act on Animal Experimentation.

Cell culture, transfections, cycloheximide and MG132 assays. Colorectal cancer Caco-2 cells, and vimentin knockout MEFvim ${ }^{-1-}$ cells (mouse embryonic fibroblasts that lack vimentin and any other cytoplasmic intermediate filament proteins; a gift from Professor John Eriksson, Åbo Akademi University ${ }^{56}$ ) were grown in DMEM supplemented with $10 \%$ fetal calf serum, $2 \mathrm{mM} \mathrm{L-glutamine}$ and $100 \mathrm{U} / \mathrm{ml}$ penicillin/streptomycin. Both MCF7 and HEK 293-expressing FLN (HEK $293 \mathrm{FLN}$ ) cells were cultured in DMEM (Sigma-Aldrich, MO, USA) 


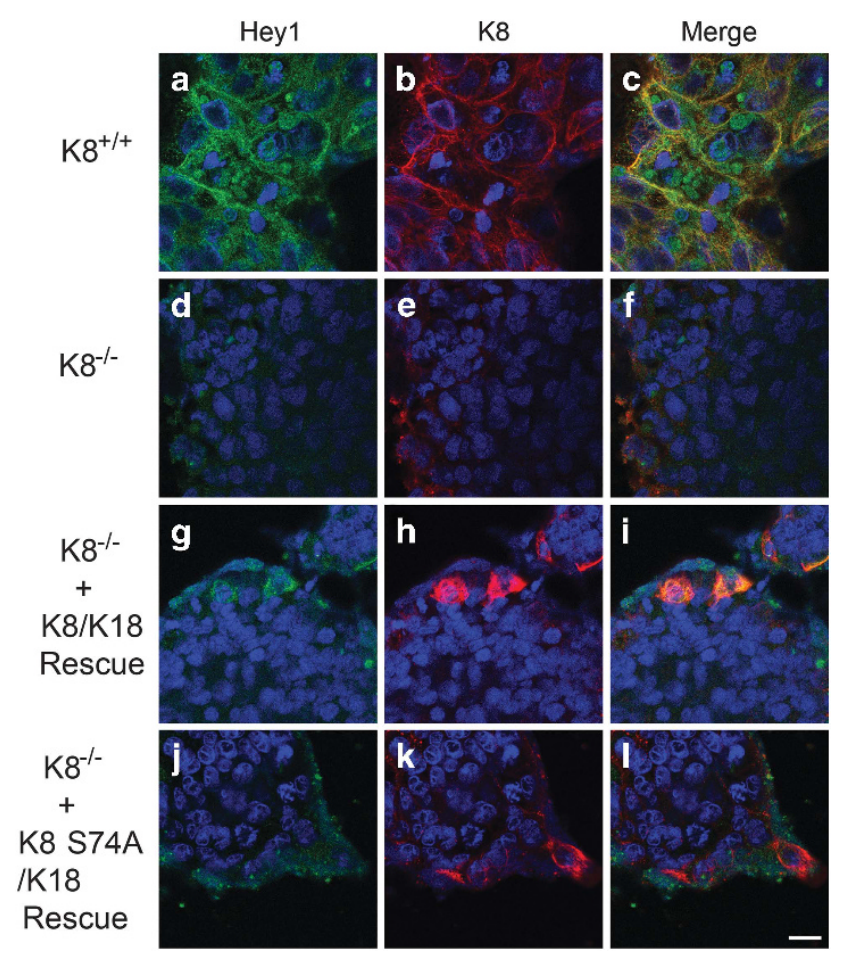

Figure 5 K8 deletion with the CRISPR/Cas9 method in Caco-2 cells downregulates Hey1 levels, which are rescued by re-expression of $\mathrm{K} 8 / \mathrm{K} 18$. Caco-2 CRISPR/Cas9 K8 ${ }^{+/+}(\mathbf{a}-\mathbf{c})$ and Caco-2 CRISPR/Cas9 K8 ${ }^{-1-}(\mathbf{d}-\mathbf{l})$ cells were cultured on cover slips, and K8/K18 or K8 S74A/K18 were overexpressed in Caco-2 CRISPR/Cas9 $\mathrm{K}^{-}{ }^{-}(\mathbf{g}-\mathbf{l})$ cells with Lipofectamine 2000. Cells were fixed with methanol and acetone in $-20^{\circ} \mathrm{C}$ and immunostained for Hey1 (Hrt1, Santa Cruz; $\mathbf{a}, \mathbf{d}, \mathbf{g}, \mathbf{j})$ and $\mathrm{K} 8(\mathbf{b}, \mathbf{e}, \mathbf{h}, \mathbf{k})$ and showed separately, or merged (c, f, i, l). Nuclei are presented in blue. $n=3$. Scale, $20 \mu \mathrm{m}$

supplemented with $10 \%$ fetal calf serum, $2 \mathrm{mM} \mathrm{L-glutamine,} 100 \mathrm{U} / \mathrm{ml}$ penicillin and $100 \mu \mathrm{g} / \mathrm{ml}$ streptomycin. For HEK $293 \mathrm{FLN}$ cells, $10 \mu \mathrm{g} / \mathrm{ml}$ puromycin was added to DMEM. All cells were cultured at $37^{\circ} \mathrm{C}$ in a $5 \% \mathrm{CO}_{2}$ atmosphere. K8-knockout Caco-2 cells and corresponding control Caco-2 cells with normal K8 levels were generated by CRISPR/Cas9 technology as previously described. ${ }^{26} \mathrm{~K}^{-/-}$and $\mathrm{K}^{+/+}$ CRISPR/Cas 9 cells were rescued by transfecting $2 \mu \mathrm{g}$ human $\mathrm{K} 8$ and human $\mathrm{K} 18$ DNA, or with NICD-GFP-Flag with Lipofectamine 2000 (Invitrogen, CA, USA) for $24 \mathrm{~h}$ following the manufacturer's protocol. For transfection of MEFvim ${ }^{-l-}$ cells, cells were washed and re-suspended in $400 \mu \mathrm{l}$ Opti-MEM (Invitrogen) and placed in electroporation cuvettes (BTX, CA, USA) with $10 \mu \mathrm{g}$ DNA (human K8, K8 S74A, K18, K19, PCDNA3.1, NICD-GFP-Flag, FLN and $\triangle E$ Notch1). The cells were electroporated with Gene Pulser (Bio-Rad, CA, USA) at $975 \mu \mathrm{F}, 260 \mathrm{~V}$ and incubated at $37^{\circ} \mathrm{C}$ for $24-48 \mathrm{~h}$, and transfection efficiency was $50-60 \%$. For Notch 1 stability assays, MEFvim ${ }^{-1-}$ cells, or $\mathrm{K}^{-/-}$CRISPR/Cas9 and $\mathrm{K}^{+/+}$CRISPR/ Cas9 Caco-2 cells were treated with $10 \mu \mathrm{g} / \mathrm{ml}$ cycloheximide (Sigma-Aldrich, MO, USA) for 0-6 h, and the proteasome was inhibited with $20 \mu \mathrm{M}$ MG132 (Santa Cruz, TX, USA) for $12 \mathrm{~h}$

Immunoprecipitation. Mouse distal (DC) and proximal (PC) epithelium was isolated for immunoprecipitation by scraping the lumen-side layer of colon with a cold glass slide and lysed in $400 \mu$ l lysis buffer $(25 \mathrm{mM}$ Hepes (pH 8.0), $100 \mathrm{mM}$ $\mathrm{NaCl}, 5 \mathrm{mM}$ EDTA, $0.5 \%$ Triton X-100, $20 \mathrm{mM} \beta$-glycerophosphate, $20 \mathrm{mM}$ paranitro-phenyl phosphate, $100 \mu \mathrm{M}$ ortovandante, $0.5 \mathrm{mM}$ phnylmethanesulfonylfluoride, $1 \mathrm{mM}$ or $200 \mathrm{mM}$ dithiothreitol, complete mini protease cocktail (Roche, Switzerland)). MEFvim ${ }^{-1-}$ and HEK FLN 293 cells were transfected and washed in PBS for immunoprecipitation. The colon epithelium, HEK $293 \mathrm{FLN}$ and MEFvim ${ }^{-1-}$ cells were lysed in $400 \mu$ lysis buffer. The precleared lysate was incubated with rabbit anti-K8 and rabbit anti-K18 (Professor John Eriksson, Åbo Akadem University $^{57}$ ), or mouse anti-K18 L2A1 (Professor Bishr Omary, University of Michigan), or goat anti-full length Notch c-20 (Santa Cruz) antibodies on shaker in
RT for 30 min after which $40 \mu \mathrm{l} 50 \%$ diluted protein-G/Sepharose (GE Healthcare, UK) was added to each sample for 16 or $4 \mathrm{~h}$ at $4^{\circ} \mathrm{C}$. The samples were centrifuged, washed four times in TEG buffer (20 mM Tris-HCl (pH 7.5), $1 \mathrm{mM}$ EDTA, $10 \%$ Glycerol), dissolved in Laemmli sample buffer and analysed by SDS-PAGE and western blot. The in vivo and in vitro immunoprecipitation samples are not normalized to each other. The in vitro immunoprecipitation in Figure $1 \mathrm{~b}$ was quantified by subtracting the non-antibody signal from the immunoprecipitation samples and dividing the result with the input signal.

Proximity ligation assay. Caco-2 cells were cultured on coverslips and fixed at $-20{ }^{\circ} \mathrm{C}$ for $10 \mathrm{~min}$ with methanol and $1 \mathrm{~min}$ with acetone for PLA analysis. Primary antibodies used were rabbit anti-full-length Notch c-20 (Santa Cruz), mouse anti-K8 (Progene, Germany). Mouse anti-Cox1 (Santa Cruz) was used as a negative control known not to bind to Notch1. ${ }^{58}$ A PLA kit (mouse and rabbit, Duolink, Sigma-Aldrich, MO, USA) was used where plus and minus probes were mixed into antibody dilution buffer and incubated for $1 \mathrm{~h}$ at $37^{\circ} \mathrm{C}$. After the samples were washed, samples were incubated with ligation buffer together with ligase for $30 \mathrm{~min}$ at $37^{\circ} \mathrm{C}$. Samples were thereafter amplified with amplification buffer, washed and mounted with mounting media containing DAPI (included in the PLA kit). The stained cells were analysed with Zeiss LSM780 confocal microscope and quantification was performed using particle analysis in Fiji software (NIH, MD, USA).

SDS-PAGE and western blot. Protein samples were homogenized on ice in homogenization buffer (0.187 M Tris-HCl, 3\% SDS, 5 mM EDTA, pH 6.8). ${ }^{59}$ Protein concentration was measured with BSA protein assay reagent kit (Thermo-Scientific, IL, USA), and samples were normalized and diluted in Laemmli sample buffer, heated at $95^{\circ} \mathrm{C}$ for 3-5 min and $10 \mu \mathrm{g}$ protein/sample was loaded in each well on $7-12 \%$ SDS-polyacrylamide gels. Prestained molecular weight markers (Bio-Rad) were loaded on each gel, and the molecular weights of the analysed bands are indicated on the right side on every blotpanel in the figures where $\mathrm{kD}$ refers to kilodalton. Rabbit anti- $\beta$-actin (Cell Signaling, MA, USA), rabbit anti-phosphohistone H3 (Cell Signaling), rabbit anti-histone H3 (Abcam, UK), rat anti-Hsc70 (Stressgen Bioreagents, MI, USA), rabbit anti-synaptophysin (Abcam), mouse anti-villin (Abcam), rabbit anti-full length Notch $\mathrm{c}-20$ (Santa Cruz), rat anti-Troma I (Developmental Studies Hybridoma Bank, IA, USA), rabbit anti-K8 (273) and rabbit anti-K18 (275; John Eriksson, Finland) and mouse anti-cytokeratin 4.62 (K19, Sigma-Aldrich, CA, USA) were used as primary antibodies. Anti-rabbit lgG (Promega, WI, USA), anti-rat IgG (GE Healthcare and Cell Signaling) and antimouse IgG (GE Healthcare) were used as secondary antibodies. ECL (GE Healthcare) and ECL plus (Perkin Elmer, MA, USA) were used for detection of blots on X-ray films (Super RX, Fuji Corporation, Japan). Individual bands were analysed and normalized to the loading controls Hsc70 or actin using the ImageJ Software (NIH, MD, USA).

RNA isolation and RT-PCR. Total colon RNA was isolated (from colon scrapings and total colon samples) using an RNA kit (Macherey Nagel, Germany), and the RNA quality was analysed in $1 \%$ agarose gel. A total of $1 \mu \mathrm{g}$ of each RNA sample was synthesized by reverse transcription to CDNA using a transcription kit (Promega). Target genes were amplified using specific primers (Supplementary Table S2) and KAPA probe Fast ABI Prism qPCR mix (Kapa Biosystems, MA, USA). qPCR was performed with StepOnePlus Real-Time PCR system (Applied Biosystems, CA, USA). Gene expression levels were normalized to $\beta$-Actin. Each cDNA was tested in triplicates, and the amplification was analysed using $1 \%$ agarose gel. For CRISPR/Cas9 $\mathrm{K}^{+/+}$and $\mathrm{K}^{-1-}$ Caco-2 cell mRNA analysis, total RNA was isolated, reverse transcribed to $C D N A$ and $\mathrm{qPCR}$ performed as above, but gene expression levels were normalized to GAPDH.

Alcian blue and periodic acid Schiff staining. Formalin-fixed paraffinembedded colon was sectioned, deparaffinized and incubated in $1 \%$ Alcian blue or periodic acid (Sigma-Aldrich, CA, USA) for 30 min highlighting the mucus in goblet cells. Schiff reagent (Merck, NJ, USA) was used to stain the background after periodic acid staining (PAS) after which the sections were washed, incubated in Myers hemalum (Merck) and dehydrated. For Alcian blue, after washing, the sections were counterstained in nuclear fast red solution for $5 \mathrm{~min}$, washed and dehydrated with $95 \%$ ethanol. Sections were cleared in xylene and mounted with mounting medium. Alcian blue or PAS-positive cells were quantified by dividing the number of positive goblet cells in a colonic crypt with the total amount of cells in the colonic crypts. Sections from three separate mice were stained for Alcian blue, and 
a

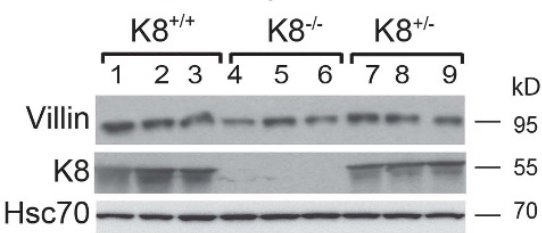

b

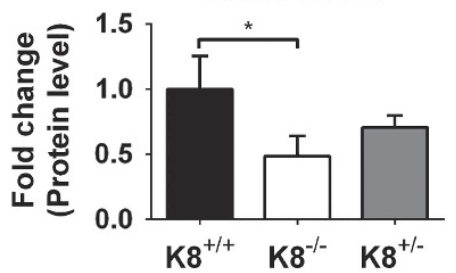

C

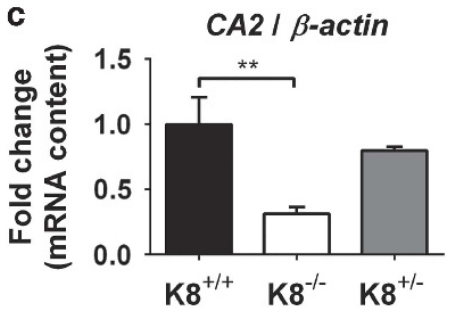

d

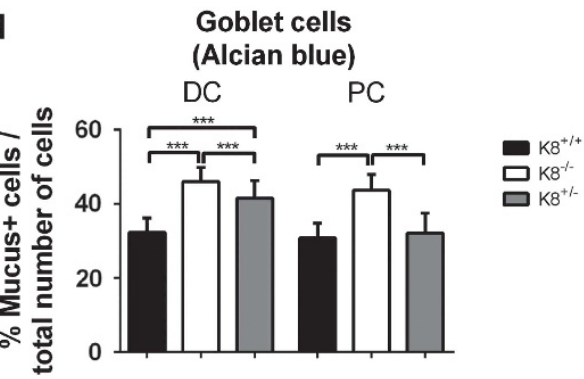

f

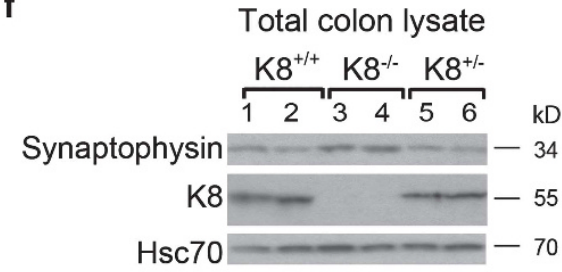

h

High signal

No signal
$\mathrm{K}^{+/+}$

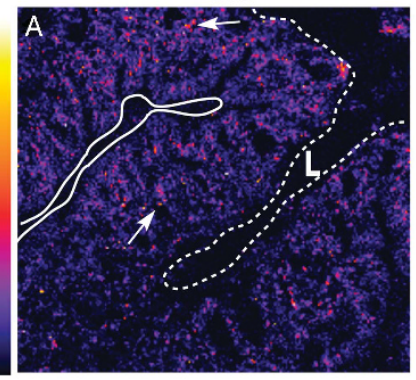

e

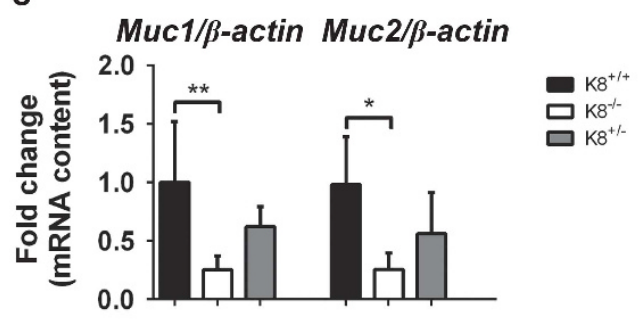

g Synaptophysin / Hsc70

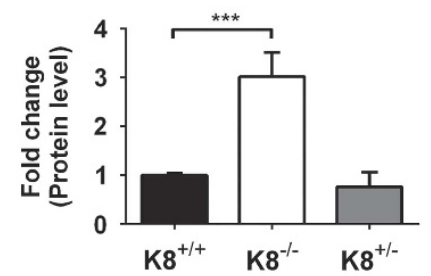

$\mathrm{K}^{-1-}$

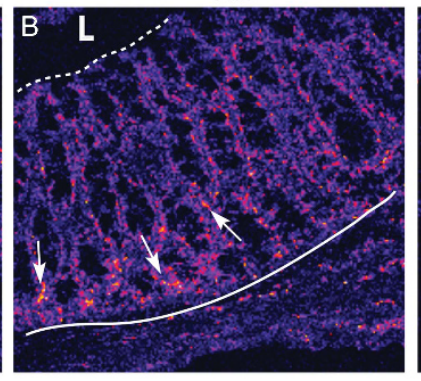

$\mathrm{K}^{+/-}$

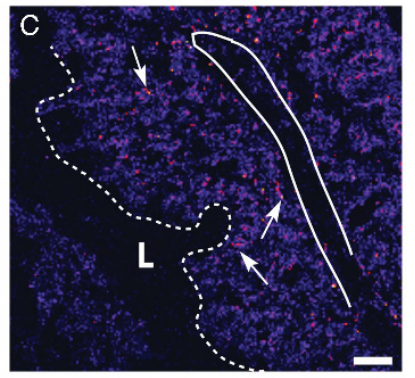

Figure 6 The colonic differentiation phenotype in $\mathrm{K}^{-1-}$ colonic epithelium is shifted towards increased goblet cells and EEC. (a) Colon epithelium was isolated by scraping and the protein levels of villin were analysed with SDS-PAGE and immunoblotting. Hsc70 was used as a loading control. Lanes 1-9 represent individual mice. $n=3$. (b) The villin protein levels in (a) were normalized to the loading control Hsc70. $n=3$. The results are presented as average fold change as related to $\mathrm{K} 8^{+/+}$control mice $\pm S D$. ${ }^{*} P<0.05$. (c) $C A 2 \mathrm{mRNA}$ was analysed in mouse colonic epithelium with RT-PCR in the indicated mouse genotypes and normalized to $\beta$-Actin. The results are presented as average fold change as related to $\mathrm{K}^{+/+}$control mice \pm SD. $n=3 .{ }^{*} P<0.01$. (d) Mucus, marking the intestinal goblet cells, was stained with Alcian blue (Supplementary Figure S4), and the mucus positive (mucus + ) goblet cells were quantified by dividing the number of goblet cells with the total number of epithelial cells per colon crypt. $n[\mathrm{DC}]=3$ mice $(10 \mathrm{crypts} / \mathrm{mouse}), n[\mathrm{PC}]=3 \mathrm{mice}(10$ crypts/mouse). ${ }^{* * *} P<0.001$. (e) Goblet cell mRNA products Mucin1 (Muc1) and Mucin2 (Muc2) were analysed with RT-PCR in the indicated mouse genotypes and were normalized to $\beta$-Actin. $n\left[\right.$ Mucin1] $=5, n[$ Mucin2 $]=4$. The results are presented as average fold change as related to $\mathrm{K}^{+/+}$control mice $\pm \mathrm{SD}$. ${ }^{*} P<0.05$. ${ }^{* *} P<0.01$. (f) Colon lysates were analysed for the EEC marker synaptophysin using SDS-PAGE and immunoblotting. Hsc70 was used as a loading control. Lanes $1-6$ represent individual mice. $n=3$. (g) The protein amount of synaptophysin from (f) was quantified and normalized to the loading control Hsc70. The results are presented as average fold change as related to $\mathrm{K} 8^{+/+}$control mice \pm SD. $n=3 .{ }^{* \star} P<0.001$. (h) Frozen colonic sections were fixed with 4\% PFA and immunostained for synaptophysin. A heat map of the positive synaptophysin staining was constructed using Biolmage XD. The dark colour represents no signal intensity and the light signal represents high signal intensity. The arrows point to examples of EEC. The border between the lumen (L) and the top of the epithelium is indicated with a dotted line and the base of the epithelial crypts by a solid line. Scale, $100 \mu \mathrm{m}$

the cells from 10 crypts per mouse were quantified so that 30 crypts per genotype were quantified.

Immunofluorescence and immunohistochemical staining. Colonic $7-\mu \mathrm{m}$ sections of $\mathrm{PC}$ and $\mathrm{DC}$ were fixed in 1-4\% paraformaldehyde (Sigma-Aldrich. CA, USA). Human Caco-2 cells were cultured and grown as described above and fixed at $-20{ }^{\circ} \mathrm{C}$ for $10 \mathrm{~min}$ with methanol and for 1 min with acetone. Cells of tissues were stained as previously described. ${ }^{59}$ Primary antibodies used were rat anti-Troma I (Developmental Hybridoma Bank, NIH, MD, USA), rabbit anti-K8 (273) and rabbit anti-K18 (275), rabbit anti-full length Notch c-20 (Santa Cruz), mouse-anti Notch1 (A6; Thermo Scientific), rabbit anti-Hrt1 (Hey1, Santa Cruz), rabbit antiphosphohistone $\mathrm{H} 3$ (Cell Signaling) and rabbit anti-synaptophysin (Abcam). Secondary antibodies used were donkey anti-rabbit conjugated with Alexa Fluor 488 (Invitrogen) and goat anti-rat conjugated with Alexa Fluor 546 (Invitrogen). 
a

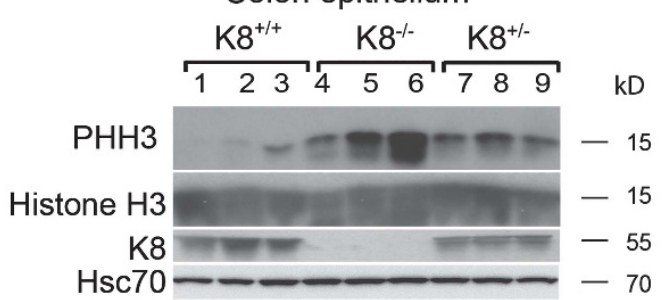

b

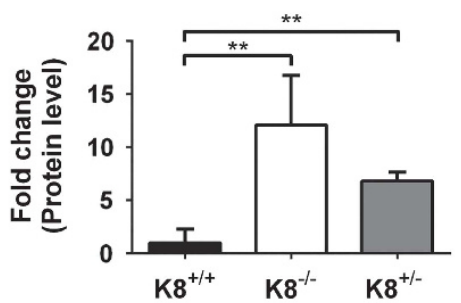

c

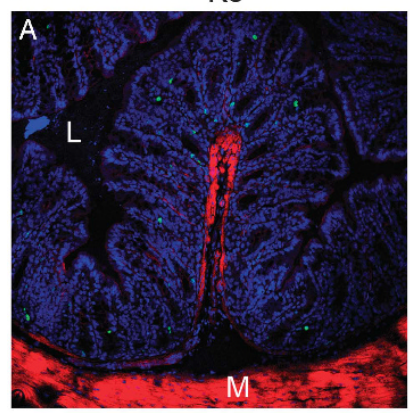

$\mathrm{K}^{-1-}$

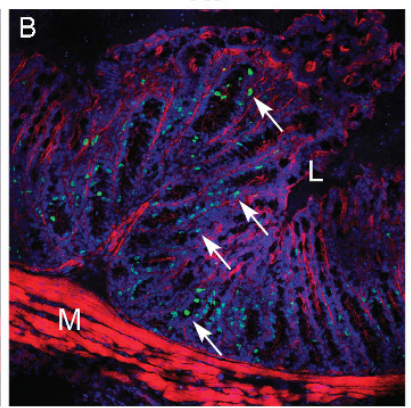

$\mathrm{K}^{+/-}$

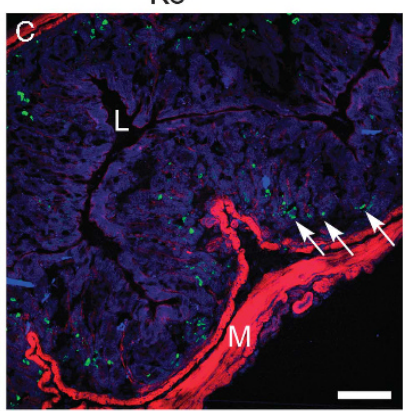

$\mathrm{PHH} 3$ F-actin Nucleus

Figure 7 Deletion of K8 leads to an increased amount of transit amplifying cells in the colonic epithelium. (a) Colonic epithelium isolated by scraping was analysed with SDSPAGE and immunoblotting for the indicated proteins. $\mathrm{PHH} 3$ was used as a marker of colonic epithelial transit amplifying cells. The genotypes were confirmed by K8 immunoblotting, and $\mathrm{Hsc70}$ was used as a loading control. Lanes 1-9 represent individual mice. $n=3$. (b) The protein amount of PHH3 from (a) was normalized to histone H3 levels (a) in order to quantify the transit amplifying cell marker of each genotype. Each column represents three genotypes presented as average fold change as related to $\mathrm{K}^{+/+}$ control mice $\pm S D,{ }^{*} P<0.01$. (c) Frozen colonic sections were fixed with $4 \%$ PFA and immunostained with rabbit anti-PHH3 (green) and phalloidin recognizing F-Actin (red). Nuclei are presented in blue. The arrows point to examples of transit amplifying cells and representative images of $n=3$ mice are shown. $L=$ lumen, $M=$ muscle. Scale, $100 \mu \mathrm{m}$

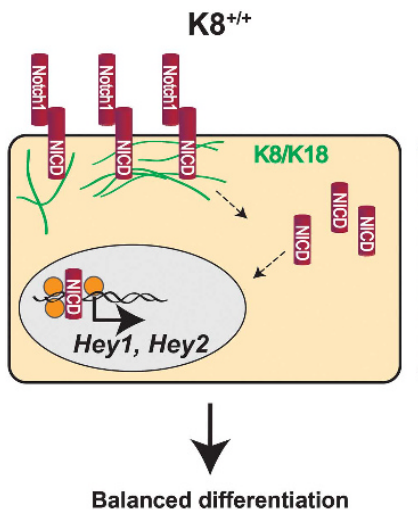

Enterocytes

Goblet cells

Enteroendocrine cells

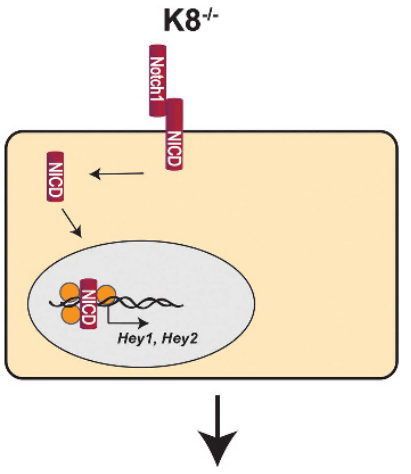

Shifted differentiation

Enterocytes

Goblet cells Enteroendocrine cells

Figure 8 Summary of the impact of keratins on the Notch1 signalling pathway. K8/K18 bind Notch1, which increases NICD levels and enhances transcription of Notch1 target genes Hey1 and Hey2. Therefore, the lack of $\mathrm{K} 8$ in the $\mathrm{K}^{-1-}$ colon leads to decreased levels of FLN and NICD, and thus decreased target gene transcription. The lack of keratins leads to a Notch1-dependent shift in colonic epithelial cell differentiation with elevated number of goblet cells and EEC and a decreased number of enterocytes

Draq5 (Cell Signaling) or DAPI (Invitrogen) were used to stain DNA, and Phalloidin (Invitrogen) to stain F-Actin. ProLong gold antifade reagent (Invitrogen) was used for mounting coverslips. Leica TCS SP5 confocal microscope with dry objective HC Plan Apo ×20/0.70 NA (Figure 6h and 7c) and a photomultiplier tube was used for image detection at room temperature using the Leica LAS AF acquisition software.

Zeiss LSM780 confocal microscope with $\times 63 / 1.2$ water objective was used for image detection (Figures 1d, 4e, 5, Supplementary Figures S2). Zeiss Zen image software was used for image analysis. Heatmap images (Figure $6 \mathrm{~h}$ ) from confocal microscopy data were created with the BiolmageXD software. ${ }^{60}$ All images in the individual panels were acquired with the same settings and adjusted for brightness and contrast identically using Photoshop CS5 (Adobe, CA, USA).

Immunohistochemistry staining on paraffin-embedded colon sections was performed at the Department of Pathology, University of Turku Hospital. Sections were fixed in 4\% PFA, incubated with rabbit anti-cleaved Notch1 (Abcam) primary antibody and secondary antibody conjugated to HRP. Sections were analysed with the Panoramic 250 Slide Scanner and Pannoramic Viewer was used for image acquisition using $\times 20$ (Supplementary Figure S3) and $\times 40$ (Figure 3d) settings.

Statistical analyses. Cell culture and animal experiments were repeated three or more times. One-way Anova with Bonferroni's post hoc test or two-tailed Student's $t$-test (GraphPad Prism Software, CA, USA) were used to determine the statistical difference. $P$ values of ${ }^{*} P<0.05$, ${ }^{* \star} P<0.01,{ }^{* *} P<0.001$ were considered as significant with $95 \%$ confidence interval.

\section{Conflict of Interest}

The authors declare no conflict of interest.

Acknowledgements. We thank Helena Saarento, Jonas Silvander, Joel Nyström, Terhi Helenius and other members of the Toivola laboratory (Biosciences, Faculty of Science and Engineering, Åbo Akademi University; ÅAU), members of Sahlgren, Sistonen and Eriksson laboratories (Turku Center of Biotechnology, University of Turku and ÅAU/ Cell Biology ÅAU) as well as Turku Center of Biotechnology Cell Imaging Core and Pasi Kankaanpää for technical support, samples and advice. Professor Bishr Omary is also acknowledged for the L2A1 antibody. This work was financed by the Academy of Finland 140759/126161 (Diana M Toivola) and 218062 (Cecilia Sahlgren), Sigrid Juselius Foundation, Liv och Hälsa foundation (Diana M Toivola), EU FP7 IRG (Diana M Toivola), ÅAU Center of Excellence of Cell Stress and Molecular Aging (Diana M Toivola, Cecilia Sahlgren), 
Swedish Cultural Foundation (Iris AK Lähdeniemi, Christian JM Antila, Sebastian K-J Landor), Turku Doctoral Programme in Molecular Biosciences at ÅAU (Iris AK Lähdeniemi), Turku Doctoral Programme of Biomedical Sciences (Julia O Misiorek), Åbo Akademi foundation (Julia O Misiorek) and Oskar Öflund Foundation (Julia O Misiorek), K Albin Johansson foundation (Julia O Misiorek, Sebastian K-J Landor), Magnus Ehrnrooth Foundation (Sebastian K-J Landor), Waldemar von Frenckell Foundation (Sebastian K-J Landor), the Swedish Research Council, EU (ITN NotchIT, Sebastian K-J Landor).

\section{Author contributions}

Iris AK Lähdeniemi, Christian JM Antila, Julia O Misiorek, Lina E Fortelius, Sebastian K-J Landor, Carl-Gustaf A Stenvall, Cecilia Sahlgren and Diana M Toivola conceived and designed the experiments. Iris AK Lähdeniemi, Julia O Misiorek, Christian JM Antila, Lina E Fortelius, Sebastian K-J Landor, Diana M Toivola, Carl-Gustaf A Stenvall and Linda K Bergström performed the experiments. Iris AK Lähdeniemi, Julia O Misiorek, Christian JM Antila, Lina E Fortelius, Sebastian K-J Landor, Carl-Gustaf A Stenvall, Cecilia Sahlgren and Diana M Toivola analysed the data. Iris AK Lähdeniemi, Cecilia Sahlgren and Diana M Toivola composed the manuscript. Julia $O$ Misiorek and Christian JM Antila contributed equally to this manuscript. Cecilia Sahlgren and Diana M Toivola contributed equally to this manuscript.

1. Toivola DM, Strnad P, Habtezion A, Omary MB. Intermediate filaments take the heat as stress proteins. Trends Cell Biol 2010; 20: 79-91.

2. Garrod DR. Desmosomes and hemidesmosomes. Curr Opin Cell Biol 1993; 5: 30-40.

3. Styers ML, Salazar G, Love R, Peden AA, Kowalczyk AP, Faundez V. The endo-lysosomal sorting machinery interacts with the intermediate filament cytoskeleton. Mol Biol Cell 2004; 15: 5369-5382.

4. Toivola DM, Krishnan S, Binder HJ, Singh SK, Omary MB. Keratins modulate colonocyte electrolyte transport via protein mistargeting. J Cell Biol 2004; 164: 911-921.

5. Loschke F, Seltmann K, Bouameur JE, Magin TM. Regulation of keratin network organization. Curr Opin Cell Biol 2015; 32C: 56-64.

6. Pan X, Hobbs RP, Coulombe PA. The expanding significance of keratin intermediate filaments in normal and diseased epithelia. Curr Opin Cell Biol 2013; 25: 47-56.

7. Omary MB. 'IF-pathies': a broad spectrum of intermediate filament-associated diseases. J Clin Invest 2009; 119: 1756-1762.

8. Toivola DM, Boor P, Alam C, Strnad P. Keratins in health and disease. Curr Opin Cell Biol 2015; 32C: 73-81.

9. Snider NT, Omary MB. Post-translational modifications of intermediate filament proteins: mechanisms and functions. Nat Rev Mol Cell Biol 2014; 15: 163-177.

10. Zhou Q, Toivola DM, Feng N, Greenberg HB, Franke WW, Omary MB. Keratin 20 helps maintain intermediate filament organization in intestinal epithelia. Mol Biol Cell 2003; 14: 2959-2971.

11. Asghar MN, Silvander JS, Helenius TO, Lahdeniemi IA, Alam C, Fortelius LE et al. The amount of keratins matters for stress protection of the colonic epithelium. PLOS ONE 2015; 10: 0127436 .

12. Baribault H, Penner J, lozzo RV, Wilson-Heiner M. Colorectal hyperplasia and inflammation in keratin 8-deficient FVB/N mice. Genes Dev 1994; 8: 2964-2973.

13. Habtezion A, Toivola DM, Asghar MN, Kronmal GS, Brooks JD, Butcher EC et al. Absence of keratin 8 confers a paradoxical microflora-dependent resistance to apoptosis in the colon. Proc Natl Acad Sci USA 2011; 108: 1445-1450.

14. Habtezion A, Toivola DM, Butcher EC, Omary MB. Keratin-8-deficient mice develop chronic spontaneous Th2 colitis amenable to antibiotic treatment. J Cell Sci 2005; 118(Pt 9): 1971-1980.

15. Asghar MN, Priyamvada S, Nystrom JH, Anbazhagan AN, Dudeja PK, Toivola DM. Keratin 8 knockdown leads to loss of the chloride transporter DRA in the colon. Am J Physiol Gastrointest Liver Physiol 2016; 310: G1147-G1154.

16. Schepers A, Clevers $\mathrm{H}$. Wnt signaling, stem cells, and cancer of the gastrointestinal tract. Cold Spring Harb Perspect Biol 2012; 4: a007989.

17. Krausova M, Korinek V. Wnt signaling in adult intestinal stem cells and cancer. Cell Signal 2014; 26: 570-579.

18. Hori K, Sen A, Artavanis-Tsakonas S. Notch signaling at a glance. J Cell Sci 2013; 126(Pt 10): 2135-2140.

19. Miyamoto S, Rosenberg DW. Role of Notch signaling in colon homeostasis and carcinogenesis. Cancer Sci 2011; 102: 1938-1942.

20. Garg P, Ravi A, Patel NR, Roman J, Gewirtz AT, Merlin D et al. Matrix metalloproteinase-9 regulates MUC-2 expression through its effect on goblet cell differentiation. Gastroenterology 2007; 132: 1877-1889.

21. Jensen J, Pedersen EE, Galante P, Hald J, Heller RS, Ishibashi M et al. Control of endodermal endocrine development by Hes-1. Nat Genet 2000; 24: 36-44.

22. van Es JH, van Gijn ME, Riccio O, van den Born M, Vooijs M, Begthel H et al. Notch/gammasecretase inhibition turns proliferative cells in intestinal crypts and adenomas into goblet cells. Nature 2005; 435: 959-963.
23. Yang Q, Bermingham NA, Finegold MJ, Zoghbi HY. Requirement of Math1 for secretory cell lineage commitment in the mouse intestine. Science 2001; 294: 2155-2158.

24. VanDussen KL, Carulli AJ, Keeley TM, Patel SR, Puthoff BJ, Magness ST et al. Notch signaling modulates proliferation and differentiation of intestinal crypt base columnar stem cells. Development 2012; 139: 488-497.

25. Sjogvist M, Antfolk D, Ferraris S, Rraklli V, Haga C, Antila C et al. PKCzeta regulates Notch receptor routing and activity in a Notch signaling-dependent manner. Cell Res 2014; 24: 433-450.

26. Misiorek JO, Lahdeniemi IA, Nystrom JH, Paramonov VM, Gullmets JA, Saarento $\mathrm{H}$ et al. Keratin 8-deletion induced colitis predisposes to murine colorectal cancer enforced by the inflammasome and IL-22 pathway. Carcinogenesis 2016; 37: 777-786.

27. Becker S, Oelschlaeger TA, Wullaert A, Vlantis K, Pasparakis M, Wehkamp J et al. Bacteria regulate intestinal epithelial cell differentiation factors both in vitro and in vivo. PIOS ONE 2013; 8: e55620.

28. Coulombe PA, Omary MB. 'Hard' and 'soft' principles defining the structure, function and regulation of keratin intermediate filaments. Curr Opin Cell Biol 2002; 14: 110-122.

29. Fuchs E, Weber K. Intermediate filaments: structure, dynamics, function, and disease. Annu Rev Biochem 1994; 63: 345-382.

30. Robine S, Jaisser F, Louvard D. Epithelial cell growth and differentiation. IV. Controlled spatiotemporal expression of transgenes: new tools to study normal and pathological states. Am J Physiol 1997; 273(4 Pt 1): G759-G762.

31. Thanasupawat T, Hammje K, Adham I, Ghia JE, Del Bigio MR, Krcek J et al. INSL5 is a novel marker for human enteroendocrine cells of the large intestine and neuroendocrine tumours. Oncol Rep 2013; 29: 149-154.

32. Mantani $\mathrm{Y}$, Yuasa H, Nishida M, Takahara E, Omotehara T, Udayanga KG et al. Peculiar composition of epithelial cells in follicle-associated intestinal crypts of Peyer's patches in the rat small intestine. J Vet Med Sci 2014; 76: 833-838.

33. Kim YS, Ho SB. Intestinal goblet cells and mucins in health and disease: recent insights and progress. Curr Gastroenterol Rep 2010; 12: 319-330.

34. Colman H, Giannini C, Huang L, Gonzalez J, Hess K, Bruner J et al. Assessment and prognostic significance of mitotic index using the mitosis marker phospho-histone $\mathrm{H} 3$ in low and intermediate-grade infiltrating astrocytomas. Am J Surg Pathol 2006; 30: 657-664.

35. Mamaeva V, Rosenholm JM, Bate-Eya LT, Bergman L, Peuhu E, Duchanoy A et al. Mesoporous silica nanoparticles as drug delivery systems for targeted inhibition of Notch signaling in cancer. Mol Ther 19: 1538-1546.

36. Desai D, Prabhakar N, Mamaeva V, Karaman DS, Lahdeniemi IA, Sahlgren C et al. Targeted modulation of cell differentiation in distinct regions of the gastrointestinal tract via oral administration of differently PEG-PEI functionalized mesoporous silica nanoparticles. Int J Nanomedicine 2016; 11: 299-313

37. Fu DJ, Thomson C, Lunny DP, Dopping-Hepenstal PJ, McGrath JA, Smith FJ et al. Keratin 9 is required for the structural integrity and terminal differentiation of the palmoplantar epidermis. J Invest Dermatol 2014; 134: 754-763.

38. Hobbs RP, Batazzi AS, Han MC, Coulombe PA. Loss of keratin 17 induces tissue-specific cytokine polarization and cellular differentiation in HPV16-driven cervical tumorigenesis in vivo. Oncogene 2016; 35: 5653-5662.

39. Haigis KM, Kendall KR, Wang Y, Cheung A, Haigis MC, Glickman JN et al. Differential effects of oncogenic K-Ras and N-Ras on proliferation, differentiation and tumor progression in the colon. Nat Genet 2008; 40: 600-608.

40. Asfaha S, Hayakawa Y, Muley A, Stokes S, Graham TA, Ericksen RE et al. Krt19(+)/Lgr5(-) cells are radioresistant cancer-initiating stem cells in the colon and intestine. Cell Stem Cell 2015; 16: 627-638

41. Alam CM, Silvander JS, Daniel EN, Tao GZ, Kvarnstrom SM, Alam P et al. Keratin 8 modulates beta-cell stress responses and normoglycaemia. J Cell Sci 2013; 126(Pt 24): 5635-5644.

42. Toivola DM, Tao GZ, Habtezion A, Liao J, Omary MB. Cellular integrity plus: organelle-related and protein-targeting functions of intermediate filaments. Trends Cell Biol 2005; 15: 608-617.

43. Vijayaraj $P$, Kroger $C$, Reuter U, Windoffer R, Leube RE, Magin TM. Keratins regulate protein biosynthesis through localization of GLUT1 and -3 upstream of AMP kinase and raptor. $J$ Cell Biol 2009; 187: 175-184.

44. Green KJ, Bohringer M, Gocken T, Jones JC. Intermediate filament associated proteins. Adv Protein Chem 2005; 70: 143-202.

45. Pallari HM, Eriksson JE. Intermediate filaments as signaling platforms. Sci STKE 2006; 2006: pe53.

46. Ramakrishnan G, Davaakhuu G, Chung WC, Zhu H, Rana A, Filipovic A et al. AKT and 14-3-3 regulate Notch4 nuclear localization. Sci Rep 2015; 5: 8782.

47. Helenius TO, Antman CA, Asghar MN, Nystrom JH, Toivola DM. Keratins are altered in intestinal disease-related stress responses. Cells 2016; 5: pii: E35.

48. Shih $\mathrm{AH}, \mathrm{Holland} \mathrm{EC}$. Notch signaling enhances nestin expression in gliomas. Neoplasia 2006; 8: 1072-1082.

49. Mellodew K, Suhr R, Uwanogho DA, Reuter I, Lendahl U, Hodges $\mathrm{H}$ et al. Nestin expression is lost in a neural stem cell line through a mechanism involving the proteasome and Notch signalling. Brain Res Dev Brain Res 2004; 151: 13-23.

50. Wilhelmsson U, Faiz M, de Pablo Y, Sjoqvist M, Andersson D, Widestrand A et al. Astrocytes negatively regulate neurogenesis through the Jagged1-mediated Notch pathway. Stem Cells 2012; 30: 2320-2329.

51. Alam H, Sehgal L, Kundu ST, Dalal SN, Vaidya MM. Novel function of keratins 5 and 14 in proliferation and differentiation of stratified epithelial cells. Mol Biol Cell 2011; 22: 4068-4078. 
52. Sakamoto K, Fujii T, Kawachi H, Miki Y, Omura K, Morita K et al. Reduction of NOTCH1 expression pertains to maturation abnormalities of keratinocytes in squamous neoplasms. Lab Invest 2012; 92: 688-702.

53. Chen Y, Guldiken N, Spurny M, Mohammed HH, Haybaeck J, Pollheimer MJ et al. Loss of keratin 19 favours the development of cholestatic liver disease through decreased ductular reaction. J Pathol 2015; 237: 343-354.

54. Zhong B, Strnad P, Toivola DM, Tao GZ, Ji X, Greenberg HB et al. Reg-ll is an exocrine pancreas injury-response product that is up-regulated by keratin absence or mutation Mol Biol Cell 2007; 18: 4969-4978.

55. Ortega-Cava CF, Ishihara S, Rumi MA, Kawashima K, Ishimura N, Kazumori H et al. Strategic compartmentalization of Toll-like receptor 4 in the mouse gut. J Immunol 2003; 170: 3977-3985.

56. Hyder CL, Kemppainen K, Isoniemi KO, Imanishi SY, Goto H, Inagaki M et al. Sphingolipids inhibit vimentin-dependent cell migration. J Cell Sci 2015; 128: 2057-2069.

57. Toivola DM, Goldman RD, Garrod DR, Eriksson JE. Protein phosphatases maintain the organization and structural interactions of hepatic keratin intermediate filaments. J Cell Sci 1997; 110(Pt 1): 23-33.

58. Santio NM, Landor SK, Vahtera L, Yla-Pelto J, Paloniemi E, Imanishi SY et al. Phosphorylation of Notch1 by Pim kinases promotes oncogenic signaling in breast and prostate cancer cells. Oncotarget 2016; 7: 43220-43238.
59. Ku NO, Toivola DM, Zhou Q, Tao GZ, Zhong B, Omary MB. Studying simple epithelial keratins in cells and tissues. Methods Cell Biol 2004; 78: 489-517.

60. Kankaanpaa P, Paavolainen L, Tiitta S, Karjalainen M, Paivarinne J, Nieminen J et al BiolmageXD: an open, general-purpose and high-throughput image-processing platform. Nat Methods 2012; 9: 683-689.

(c) (i) This work is licensed under a Creative Commons Attribution 4.0 International License. The images or other third party material in this article are included in the article's Creative Commons license, unless indicated otherwise in the credit line; if the material is not included under the Creative Commons license, users will need to obtain permission from the license holder to reproduce the material. To view a copy of this license, visit http:// creativecommons.org/licenses/by/4.0/

(C) The Author(s) 2017

Supplementary Information accompanies this paper on Cell Death and Differentiation website (http://www.nature.com/cdd) 